\title{
RAZPRAVE
}

\section{MORFOLOŠKA TIPOLOGIJA STANOVANJSKIH OBMOČIJ V LJUBLJANI}

\author{
AVTORJI \\ dr. Jernej Tiran \\ Znanstvenoraziskovalni center Slovenske akademije znanosti in umetnosti, Geografski inštitut Antona Melika, \\ Gosposka ulica 13, SI - 1000 Ljubljana, Slovenija \\ jernej.tiran@zrc-sazu.si
}

\section{dr. David Bole}

Znanstvenoraziskovalni center Slovenske akademije znanosti in umetnosti, Geografski inštitut Antona Melika, Gosposka ulica 13, SI - 1000 Ljubljana, Slovenija

david.bole@zrc-sazu.si

\section{Peter Kumer}

Znanstvenoraziskovalni center Slovenske akademije znanosti in umetnosti, Geografski inštitut Antona Melika, Gosposka ulica 13, SI - 1000 Ljubljana, Slovenija

peter.kumer@zrc-sazu.si

DOI: $10.3986 / G V 88103$

UDK: 911.375.62:728(497.4Ljubljana)

COBISS: 1.01

\section{IZVLEČEK}

\section{Morfološka tipologija stanovanjskih območij v Ljubljani}

$V$ prispevku je predstavljena morfološka tipologija stanovanjskih območij v Ljubljani. Izdelali smo jo na podlagi treh prvin morfološke zgradbe mesta: časa, oblike in ravni natančnosti. S kartiranjem $v$ geografskih informacijskih sistemih, podprtim s terenskim delom, različnimi podatkovnimi in zgodovinskimi viri, smo opredelili 16 značilnih morfoloških območij stanovanjskih objektov, jih prostorsko zamejili in opisali. Metodologija za določanje morfološke zgradbe je potencialno uporabna tudi za druga slovenska mesta, rezultati tipizacije pa so lahko izhodišče za urbanistično načrtovanje, ovrednotenje preteklega in današnjega prostorskega razvoja mesta ter analize v urbanizmu in urbani geografiji.

\section{KLJUČNE BESEDE}

urbana geografija, morfološka zgradba, stanovanjska območja, tipologija, Ljubljana

\section{ABSTRACT}

\section{Morphological typology of residential areas in Ljubljana}

The article presents a new morphological typology of residential areas in Ljubljana. It was created using three fundamental principles of urban morphology: time, form, and resolution. By mapping in the geographical information systems supported by the fieldwork, various data sources and historical sources, we defined 16 residential morphological areas with accurate delimitation and descriptions. The methodology for mapping urban morphology is also potentially useful for other Slovenian cities, while the typification results can be a useful basis for urban planning, the evaluation of previous and contemporary spatial development in Ljubljana, and future analysis in urbanism and urban geography. 


\section{KEY WORDS}

urban geography, urban morphology, residential areas, typology, Ljubljana

Uredništvo je prispevek prejelo 12. aprila 2016. 


\section{Uvod}

Mesto je zapleten in kompleksen družbeni in prostorski pojav. To se najbolj vidno odseva v njegovi morfološki zgradbi oziroma oblikovanosti mestnega prostora. Morfološko zgradbo razumemo kot razporeditev morfoloških elementov v prostoru, ki skupaj tvorijo grajeno okolje, v katerem se zrcalita zdajšnje in nekdanje mestno življenje (Vrišer 1984; Vresk 2002). Morfološka zgradba je sicer najstabilnejši, najbolj trdoživ element mestne zgradbe, morfogeneza - proces nastajanja in preoblikovanja fizične strukture mesta - pa bistveno počasnejši proces od funkcijske in socialne preobrazbe (Ilešič 1979).

V literaturi se najpogosteje pojavljajo naslednji elementi morfološke zgradbe: lastnosti stavb, kot so starost, gabarit, število stanovanjskih enot, oblika in gradbeni material, mestni tloris, razmerje med pozidanimi in nepozidanimi ali zaprtimi in odprtimi površinami, sklenjenost zazidave, položaj stavb glede na prometnico ter urejenost parcel v ulične bloke (Vrišer 1984; Hofmeister 1994; Carter 1995; Rebernik 2000; 2008; Čerpes, Blejec in Koželj 2008). Elementi morfološke zgradbe so torej dokaj raznovrstni, njihovi seznami pa med avtorji zelo različni. Posledično se tudi tipizacije (postopki členitve $\mathrm{v}$ homogene morfološke tipe) in tipologije (rezultati členitve) med seboj razlikujejo in so tudi regionalno pogojene (Rebernik 2008). V Sloveniji sta se z morfološko zgradbo na primerih različnih mest in naselij ukvarjala predvsem Drozg (1995; 1997; 1998b; 2008) in Rebernik (1994; 1997; 2000), ki sta tipologije izdelala na podlagi kombinacije zgodovinsko-geografskega in kvantitativnega pristopa.

Ljubljana ima zaradi dolge zgodovine in velikosti pozidanega območja v primerjavi z ostalimi slovenskimi mesti zelo pestro morfološko zgradbo, ki je bila doslej najbolj temeljito analizirana v dveh raziskavah. Rebernik (2000) je na podlagi treh morfoloških elementov (mestni tloris, tip zazidave in tip stavb) določil 10 značilnih stanovanjskih morfoloških območij, Dimitrovska Andrews, Mihelič in Stanič (2001) pa so na podlagi starosti, funkcije in zazidalnega sistema opredelili 15 značilnih homogenih mestnih območij, ki dajejo mestu identiteto in hkrati razkrivajo njegov zgodovinski razvoj. Obema raziskavama je skupno, da imata višjo raven generalizacije in ne opredeljujeta nekaterih značilnih morfoloških območij. Kompleksnejše, sodobnejše in prostorsko bolj natančne študije morfološke zgradbe Ljubljane tako za enkrat še nimamo.

Namen članka je izdelati natančnejšo morfološko tipologijo stanovanjskih območij v Ljubljani, ki bo uporabna za načrtovanje in prostorske analize. Pri tem smo si zastavili dva cilja:

- opredelitev metodoloških izhodišč za kartiranje morfološke zgradbe, potencialno uporabnih tudi za druga slovenska mesta, ter

- določitev in analiza morfoloških območij mesta.

\section{Metode}

Uporabljen metodološki pristop temelji na treh prvinah. Prva je čas. Morfološka zgradba mesta je lahko razumljena le v zgodovinskem kontekstu, saj so njene prvine pod vplivom stalne preobrazbe (Vernez Moudon 1997). Gauthiez (2004) govori o tako imenovanem zgodovinsko-geografskem pristopu pri preučevanju morfološke zgradbe mesta, kjer je pomemben čas nastanka določene morfološke enote - stavbe, ulice, trga ali drugega pozidanega območja. Čas nastanka je namreč konstanta, kjer so za določena zgodovinska obdobja značilne določene urbano-morfološke oblike (Levy 1999). V naši tipizaciji je bil temeljni podatkovni vir za to prvino starost stavb (Register nepremičnin 2014), ki smo ga kombinirali z drugimi viri, ki opisujejo zgodovinski in urbanistični razvoj mesta ter njegovih morfoloških območij (Potočnik 1929; Vogelnik 1938; Mihelič 1983; 2010; Novak 1991; Gazvoda 2001; Zupančič 2005; Batista 2010; Koselj 2010; Fikfak 2012; Černigoj 2015; Malešič 2015; Režek Kambič 2015).

Druga prvina pričujoče morfološke tipizacije je oblika, ki jo podobno kot Vernez Moudon (1997) razumemo s tremi temeljnimi fizičnimi elementi: stavbami, z njimi povezanimi odprtimi prostori in 
ulicami. Postopek tipizacije glede na oblikovne lastnosti je temeljil na terenskem delu in naslednjih vhodnih podatkih (Barvni digitalni ... 2014; Register nepremičnin 2014):

- število stanovanj v stavbi,

- tip stavb glede na obliko, velikost in etažnost ter členjenost fasade,

- položaj stavb glede na prometnico in

- položaj stavb glede na sosednje stavbe.

Tretja prvina, na kateri je temeljil metodološki pristop, je raven natančnosti in z njo povezane stopnje generalizacije. Morfološko zgradbo lahko razumemo in preučujemo na različnih prostorskih ravneh, na primer na ravni stavbe oziroma parcele, ulice oziroma uličnega bloka ali mesta. V nasprotju z Rebernikovo tipizacijo (2000) in zemljevidom morfoloških območij mesta, ki je bolj generaliziran oziroma manj natančen, smo tipizirali manjše enote mestnega tkiva in za osnovno enoto uporabili enoto urejanja prostora iz izvedbenega dela Občinskega prostorskega načrta (OPN) Mestne občine Ljubljana (2014). Zakon o prostorskem načrtovanju (2007) jo opredeljuje kot »... območje z enotnimi značilnostmi prostora, na katerem se določi namenska raba in dopustna izraba prostora ter omejitve, povezane $z$ varstvom okolja, ohranjanjem narave in varstvom kulturne dediščine ... «. OPN je uporabno izhodišče za določanje morfološke zgradbe, saj so enote urejanja prostora morfološko dokaj homogene. Vendar pa enote opredeljujejo prihodnjo (namensko) rabo in ponekod ne odsevajo nujno zdajšnje (dejanske) rabe; zato smo jih uporabili zgolj za izhodišče in jih ponekod delili na dve ali več morfoloških območij. To smo storili tam, kjer je jasno vidna ločnica med morfološkimi tipi in se ti pojavljajo v dovolj velikem obsegu (slika 1). V Trnovem smo na primer enoto TR-339 razdelili na več morfoloških območij, saj smo znotraj enote prepoznali dva morfološka tipa: območja prostostoječih enostanovanjskih hiš in območja atrijskih hiš. Nestanovanjske površine pa smo v nekaterih primerih združili s stanovanjskimi, če smo ugotovili, da gre za njihova funkcionalna zemljišča (zelenice, vrtički, pripadajoče prometne površine).

Pričujoča morfološka tipizacija se osredotoča na stanovanjska območja. Zato smo med tipiziranjem ločili območja s pretežno stanovanjsko rabo od območij s pretežno nestanovanjsko rabo (Centralni ... 2015; Evidenca ... 2015). Med nestanovanjska območja smo uvrstili zelene površine, območja storitvenih, rekreacijskih in izobraževalnih dejavnosti, prometne površine, industrijske in poslovne cone ter degradirana zemljišča.

$S$ pomočjo navedenih prvin, podatkovnih virov in terenskega dela smo izvedli kartiranje morfološke zgradbe v geografskem informacijskem sistemu s programskim paketom ArcMap 10.3. S prekrivanjem kartografskih slojev smo ugotovili tudi število prebivalcev, ki živijo v posameznih morfoloških območjih. Podatki so $\mathrm{z}$ dne 31.12. 2014 in veljajo za prebivalce s stalnim prebivališčem (Centralni ... 2015; Evidenca ... 2015). Rezultat tipizacije je tipologija morfološko homogenih stanovanjskih območij, ki smo jih ustrezno poimenovali, preučili njihove značilnosti in analizirali njihovo prostorsko razmestitev.

\section{Morfološka območja}

S tipizacijo smo opredelili 16 tipov stanovanjskih območij s specifično kombinacijo morfoloških elementov. Tipe smo razvrstili v štiri skupine glede na število stanovanjskih enot: območja enostanovanjskih hiš (poglavje 3.1), območja večstanovanjskih hiš (poglavje 3.2), mešana eno- in večstanovanjska območja (poglavje 3.3) in območja blokovske gradnje (poglavje 3.4). Morfološki tipi so podrobneje opisani v nadaljevanju in kartografsko prikazani na sliki 3.

Nastanek in razvoj morfoloških območij v Ljubljani prikazujemo na sliki 2. Obdobjem, v katerih so posamezni tipi nastajali, ni mogoče natančno določiti letnico njihovega nastanka in zatona, zato je

Slika 1: Izhodiščna prostorska enota za tipizacijo je bila enota urejanja prostora, ki smo jo ponekod nadalje delili na več morfoloških območij. 


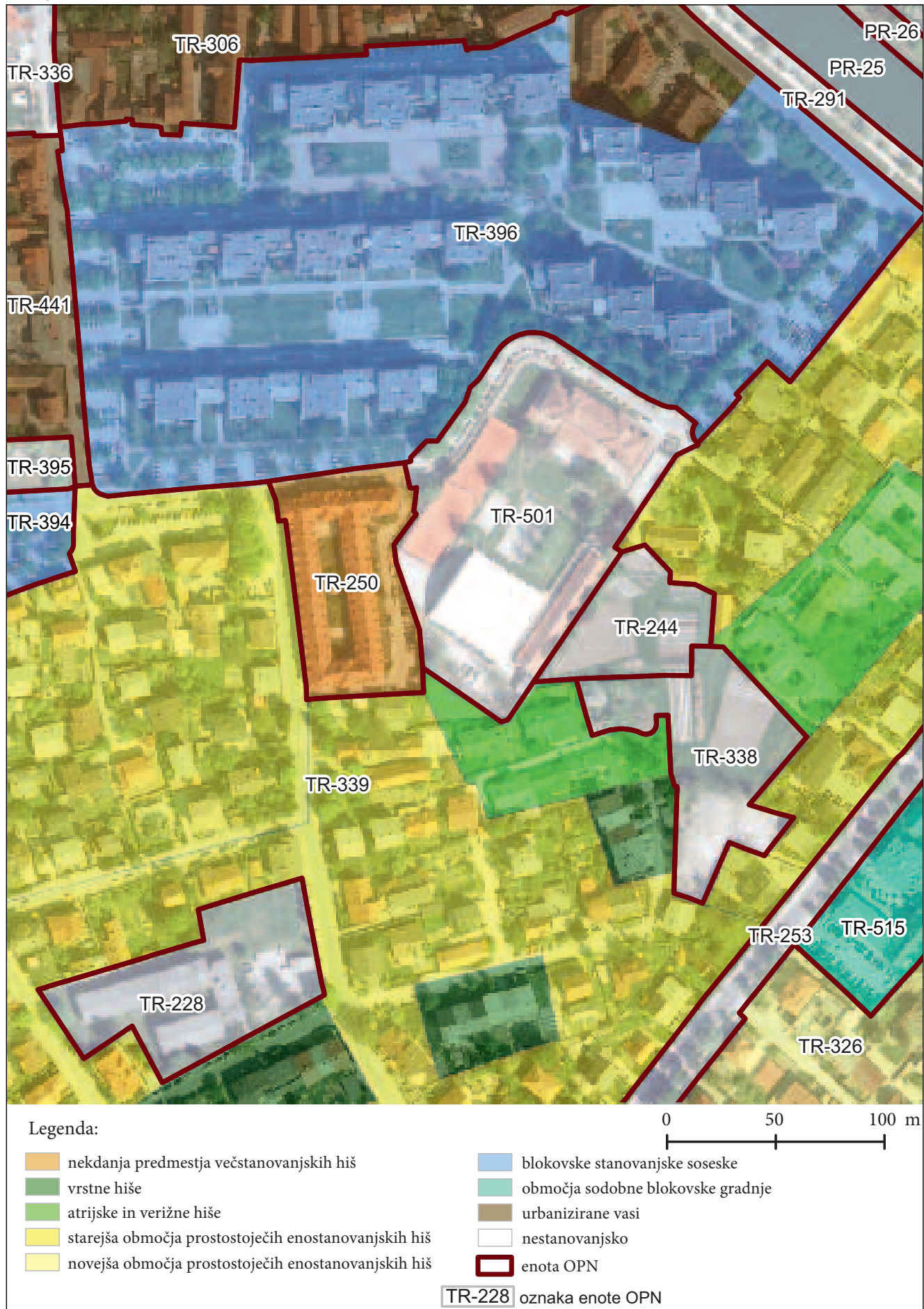

Avtorji vsebine in zemljevida: David Bole, Jernej Tiran in Peter Kumer. Vir podatkov: Občinski prostorski načrt ... 2014. (C) Geografski inštitut Antona Melika ZRC SAZU 


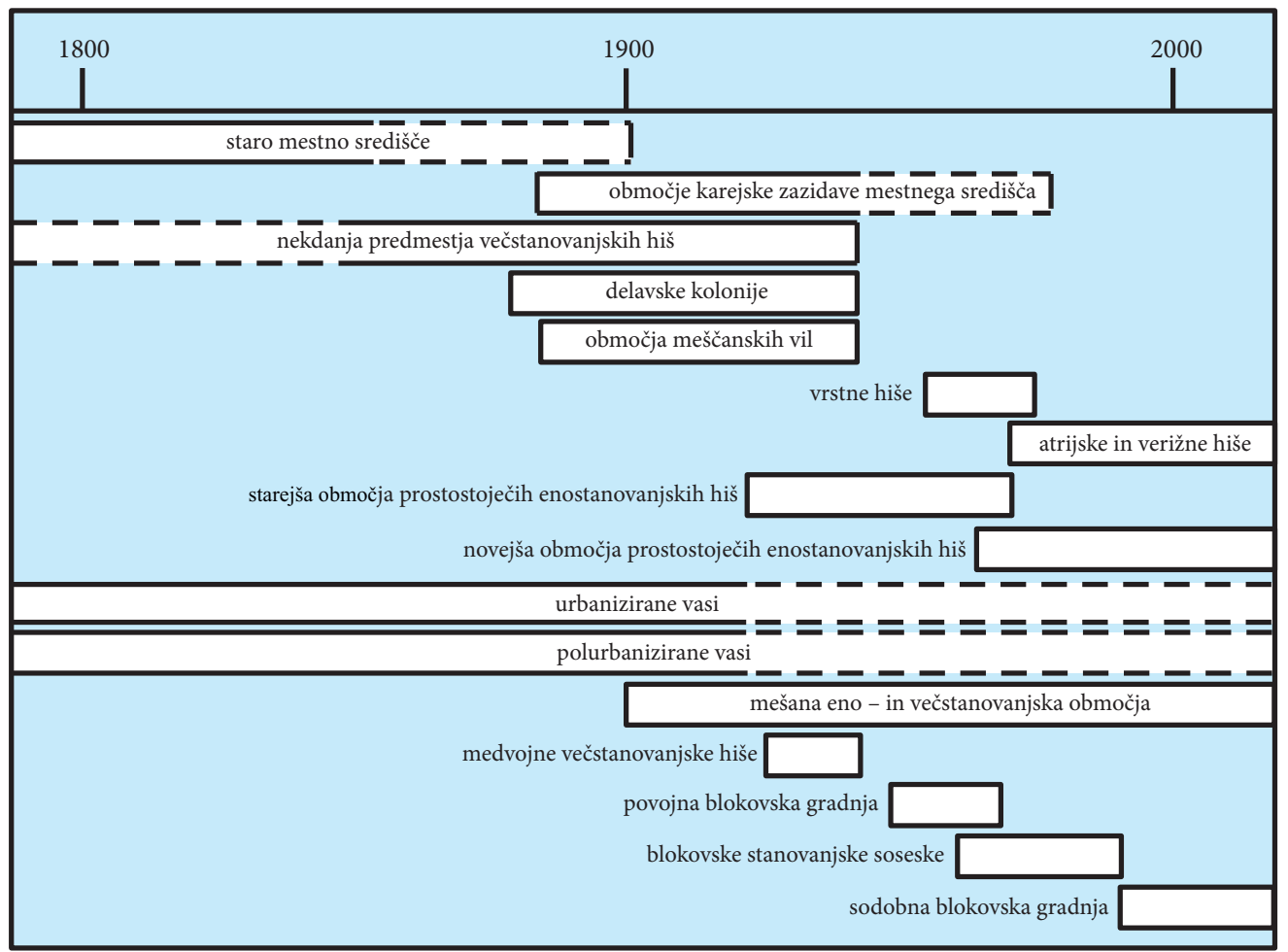

Slika 2: Kronološki prikaz nastanka morfoloških tipov v Ljubljani.

Preglednica 1: Število prebivalcev po posameznih morfoloških tipih.

blokovske stanovanjske soseske

novejša območja prostostoječih enostanovanjskih hiš

povojna blokovska gradnja

40.519

sodobna blokovska gradnja

19.975

starejša območja prostostoječih enostanovanjskih hiš

13.945

vrstne hiše

10.227

atrijske in verižne hiše

10.017

polurbanizirane vasi

7038

nekdanja predmestja večstanovanjskih hiš

6789

mešana eno- in večstanovanjska območja

6485

območje karejske zazidave mestnega središča

4189

delavske kolonije

3950

staro mestno središče

3754

urbanizirane vasi

območja meščanskih vil

medvojne večstanovanjske hiše 
prikaz bolj ilustrativnega značaja. Obdobje, ko so se območja bolj ali manj le dograjevala ali pojavljala $\mathrm{v}$ manjšem obsegu, smo označili s črtkano črto. Vidno je, da začetek in konec obdobja njihove gradnje večinoma sovpada $\mathrm{z}$ zgodovinskimi obdobji in $\mathrm{z}$ njimi povezanimi družbeno-političnimi sistemi ter urbanističnimi koncepti, ki jih podrobneje opisujemo v nadaljevanju.

Največ, 71.451 oziroma slaba četrtina prebivalcev Ljubljane živi v blokovskih stanovanjskih soseskah, skupno pa v območjih blokovske gradnje živi 131.945 prebivalcev, kar je slaba polovica. Veliko število ljudi, 53.624 oziroma približno petina, prebiva v novejših območjih prostostoječih enostanovanjskih hiš. Ostali morfološki tipi so prebivalstveno precej slabše zastopani (preglednica 1).

\subsection{Območja enostanovanjskih hiš}

\subsubsection{Starejša območja prostostoječih enostanovanjskih hiš}

Starejša območja prostostoječih enostanovanjskih hiš so večinoma nastala v obdobju med obema vojnama, vendar so se izoblikovala postopoma in se dograjevala tudi v poznejših obdobjih (Rebernik 2000). Prevladuje nesklenjena zazidava, ki jo vmes pogosto prekinjajo ostali morfološki tipi. Najpogostejši predstavnik tega morfološkega tipa je mestna enostanovanjska hiša (slika 4), ki jo Drozg (2013) označuje kot bivališče tistih meščanov, ki niso bili dovolj premožni za vilo, a bolj premožni za modificirano kmečko hišo. V Ljubljani ima ta tip hiše običajno kvadraten tloris s štirikapno piramidasto strmo streho, simetrično razporejenimi okni in dvema etažama. Nekatera območja, kjer je bil socialni položaj lastnikov boljši, hiša spominja na poenostavljeno različico vile, vendar z manjšima stanovanjsko površino in okolico stavbe. V manjšem obsegu se pojavljajo tudi dvojčki. Največja in najbolj značilna območja tega tipa so v Rožni dolini, na Kodeljevem, Koleziji in ponekod v Šiški. Drugod, zlasti za Bežigradom in v Zeleni jami, prevladuje skromnejša različica mestne enostanovanjske hiše. To posebno velja za tista območja, ki so nastala takoj po 2. svetovni vojni, kjer so hiše manjše, z manj stavbnega okrasja in kjer je njihova gostota večja. Ta morfološka območja se v sodobnosti med seboj razlikujejo po ohranjenosti in urbanistični urejenosti, skoraj vsa pa so preobražena; na območju Rožne doline in Kodeljevega ob prenovah pogosto nastajajo sodobne vile ali manjši vila bloki, ob Kamniški ulici za Bežigradom pa so se hiše povečevale in dozidavale brez pravega koncepta, tako da so ponekod nastala sklenjena večstanovanjska poslopja. Opazna je težnja, da se hiše ob prenovah spreminjajo iz enostanovanjskih $\mathrm{v}$ večstanovanjske.

\subsubsection{Novejša območja prostostoječih enostanovanjskih hiš}

Novejša območja prostostoječih enostanovanjskih hiš so zelo razširjen morfološki tip v Ljubljani, saj v njih živi približno petina prebivalcev (preglednica 1) in predstavljajo skoraj polovico vseh naseljenih stavb. Med stavbnimi tipi prevladuje nova mestna stanovanjska hiša, ki se je pojavila v 60. letih 20. stoletja. Hiša je prostostoječa, praviloma dvoetažna in podkletena, $\mathrm{z}$ dvokapno streho in pravilnim kvadratnim tlorisom. Od mestne enostanovanjske hiše se razlikuje predvsem po nižjem naklonu strehe in novih stavbnih členih, kot sta na primer terasa in garaža (Drozg 2013). Ta tip hiše se je razmahnil $s$ povojnim priseljevanjem podeželskega prebivalstva $\mathrm{v}$ Ljubljano $\mathrm{v}$ obdobju pospešene urbanizacije in industrializacije. Razširjen je po celotni Sloveniji in ima pogosto negativen prizvok zaradi uniformne oblike (»kocka» (slika 5) ali »transformator») in odsotnosti urbanistične zasnove sosesk, brez upoštevanja naravnih in kulturnih danosti (Fikfak 2012). Ta območja prevladujejo na mestnem obrobju, na primer v Bizoviku, Brodu, Zalogu in Šentvidu. V ta morfološki tip uvrščamo tudi nekatera območja današnjih enostanovanjskih hiš, ki so bila prvotno barakarska naselja (del Galjevice, Rakova Jelša, Sibirija), in morfološko izrazito preobražena prvotna območja starejših mestnih hiš, ki se mešajo z novejšimi

Slika 3: Morfološka zgradba Ljubljane. > str. 44-45 


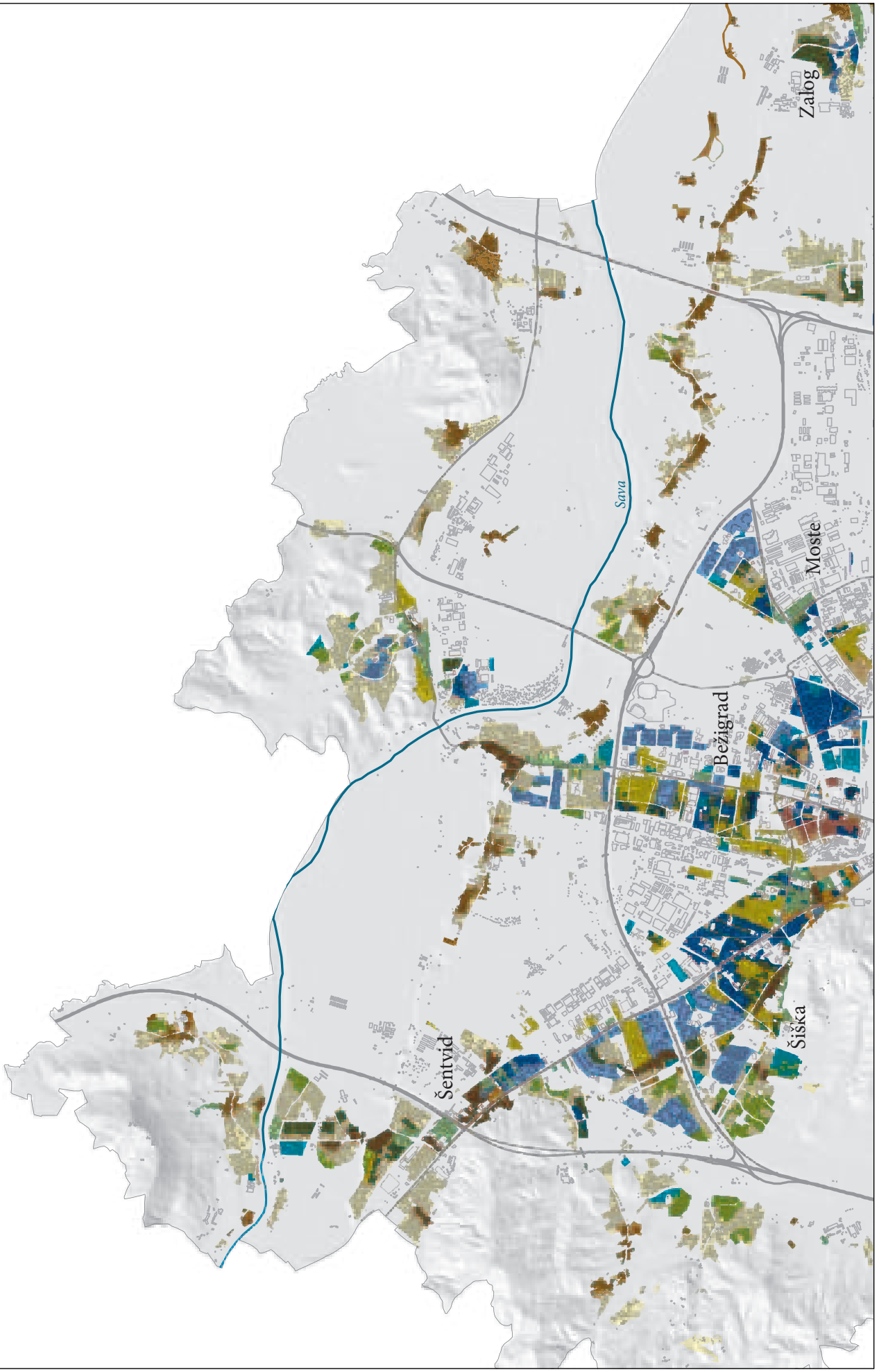




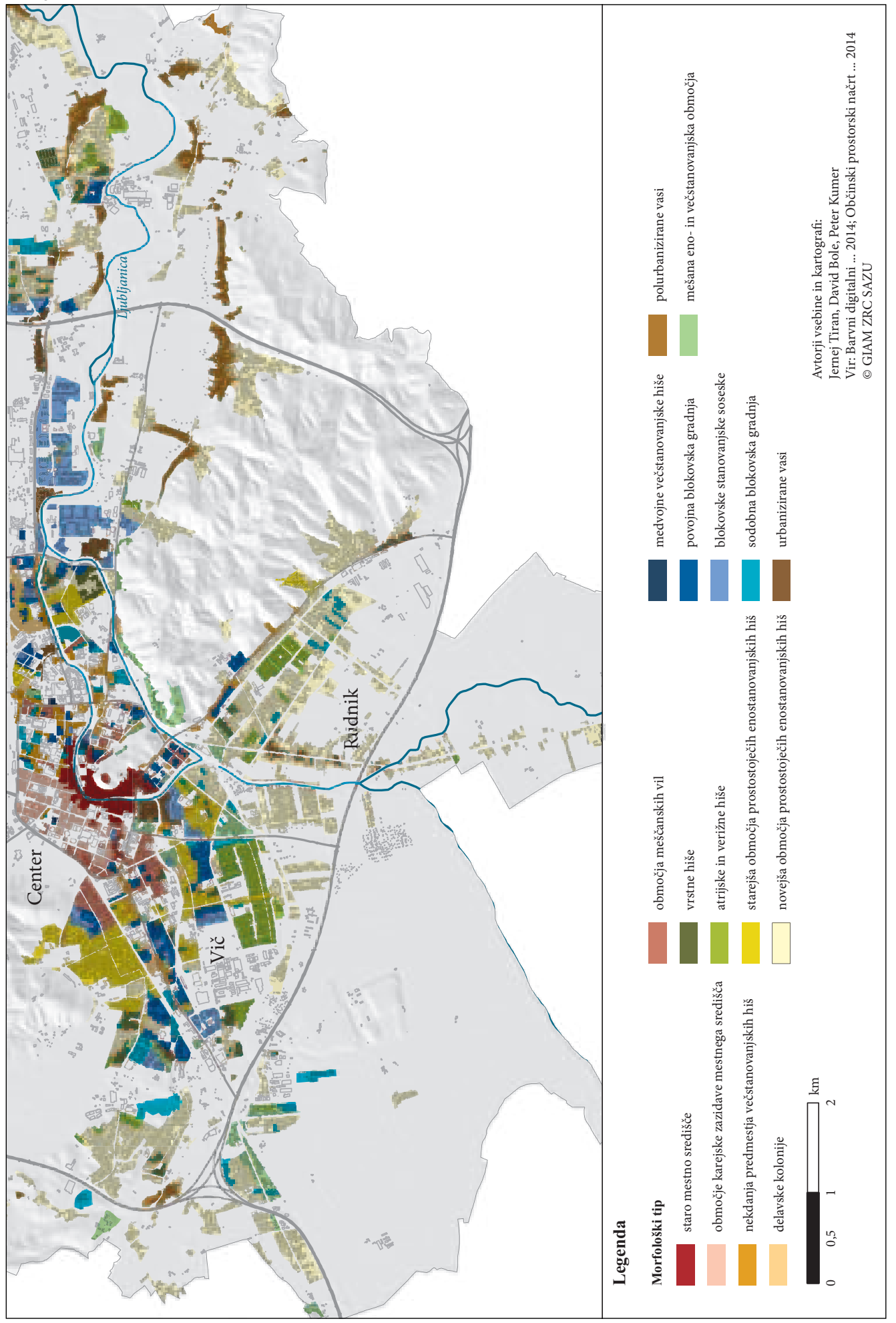


Slika 4: Mestna enostanovanjska hiša. Ob prenovah se umika drugim stavbnim tipom.
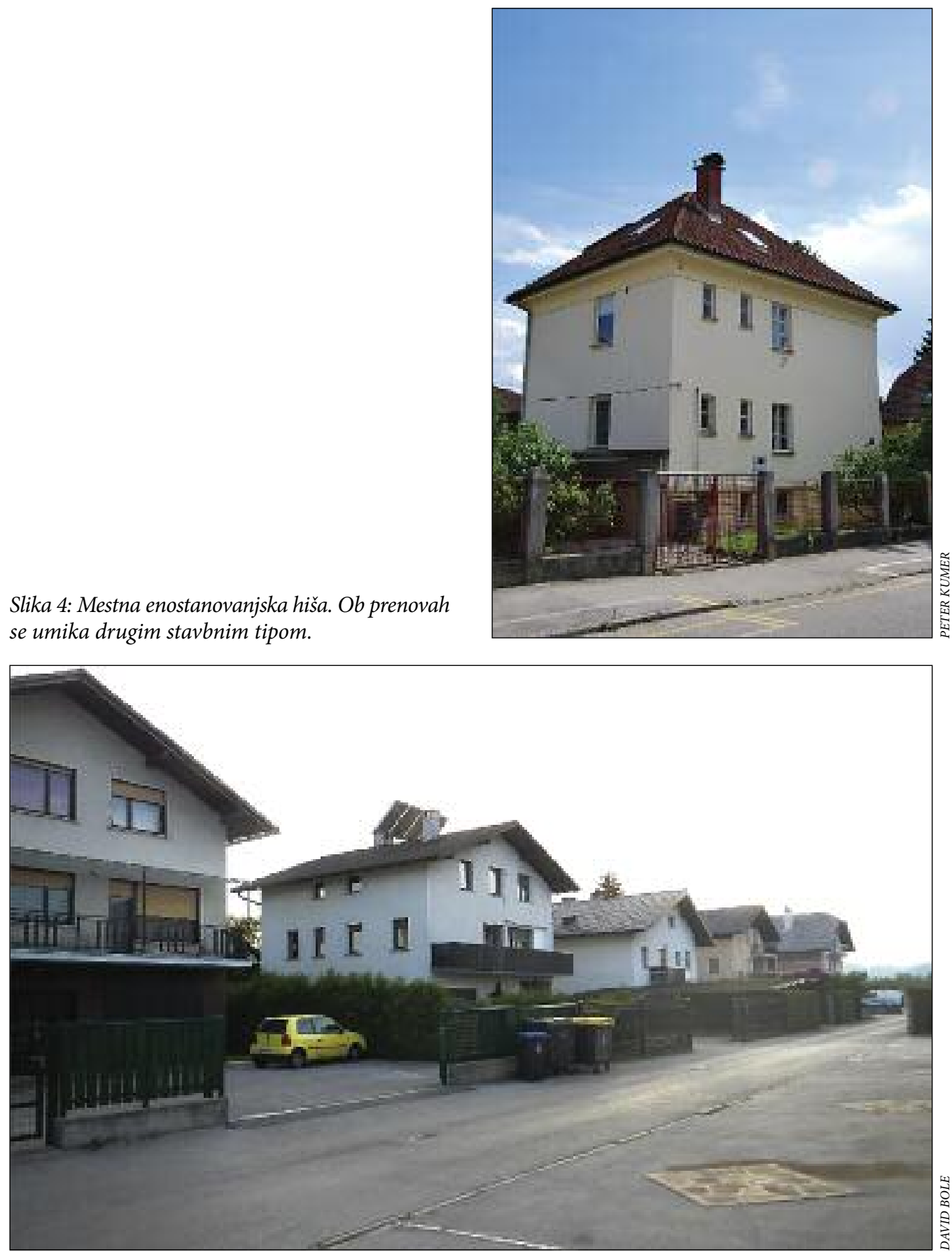

Slika 5: Enostavni, kvadratni tloris in uniformnost nove mestne stanovanjske hiše je razlog, da se je je prijela negativna oznaka »kocka«. 
eno-, pa tudi večstanovanjskimi hišami (Trnovo, Rakovnik in deli Kodeljevega). K temu morfološkemu tipu prištevamo tudi novejše enostanovanjske hiše, nastale v zadnjih dvajsetih letih, ki so arhitekturno zelo raznolike in hkrati ne tvorijo večjih sklenjenih morfoloških območij. To so na primer novejše hiše v neohistoričnem slogu ter pritlične in montažne (kataloške) hiše, ki se večinoma pojavljajo posamično in zapolnjujejo prazne prostore $\mathrm{v}$ mestu. Za te moderne hiše so značilni standardizirani elementi, ki omogočajo različne kombinacije in prilagoditve potrebam in željam kupcev, kot gradbeni material se pogosteje uporabljata steklo in kovina, strehe pa so večinoma ravne, enokapne ali ukrivljene, dvokapne so redkejše (Drozg 2013).

\subsubsection{Vrstne hiše}

Za prvo naselje vrstnih hiš v Ljubljani veljajo hiše ob Dermotovi ulici iz 30. let 20. stoletja, ki jih je zgradila Vzajemna zavarovalnica, vanje pa so se vselili mestni uradniki (Zupančič 2005). Razmah vrstnih hiš po 2. svetovni vojni je povezan $\mathrm{z}$ ustanovitvijo stanovanjskih zadrug v 50. letih 20. stoletja, ki so spodbudile kakovostnejšo individualno gradnjo, tudi kot odgovor na toge republiške stanovanjske normative. Morfološko gre za enonadstropne vrstne hiše bodisi v ravnem nizu bodisi v nekoliko bolj razgibani stavbni črti, ki so praviloma dvostransko orientirane: ena fasada na ulico, druga na zasebni vrtiček (Mihelič 1983). Hiše se pojavljajo v manjših karejih, ki so zapolnjevali proste površine v mestnem tkivu, ponekod tudi v obliki trojčkov ali četverčkov. Po izgradnji vrstnih hiš v Jaršah (leta 1952), še posebej pa na Langusovi ulici na Mirju (1955) ter Peričevi ulici za Bežigradom (1957), se je ta morfološki tip močno razširil. Konec 60. let ga je začela izpodrivati gradnja v obliki atrijskih in verižnih hiš. Območja vrstnih hiš najdemo po vsej Ljubljani, v največjem obsegu za Bežigradom (med Dunajsko in Slovenčevo cesto; slika 6), v Šiški (med Celovško in Vodnikovo cesto) in na Kodeljevem.

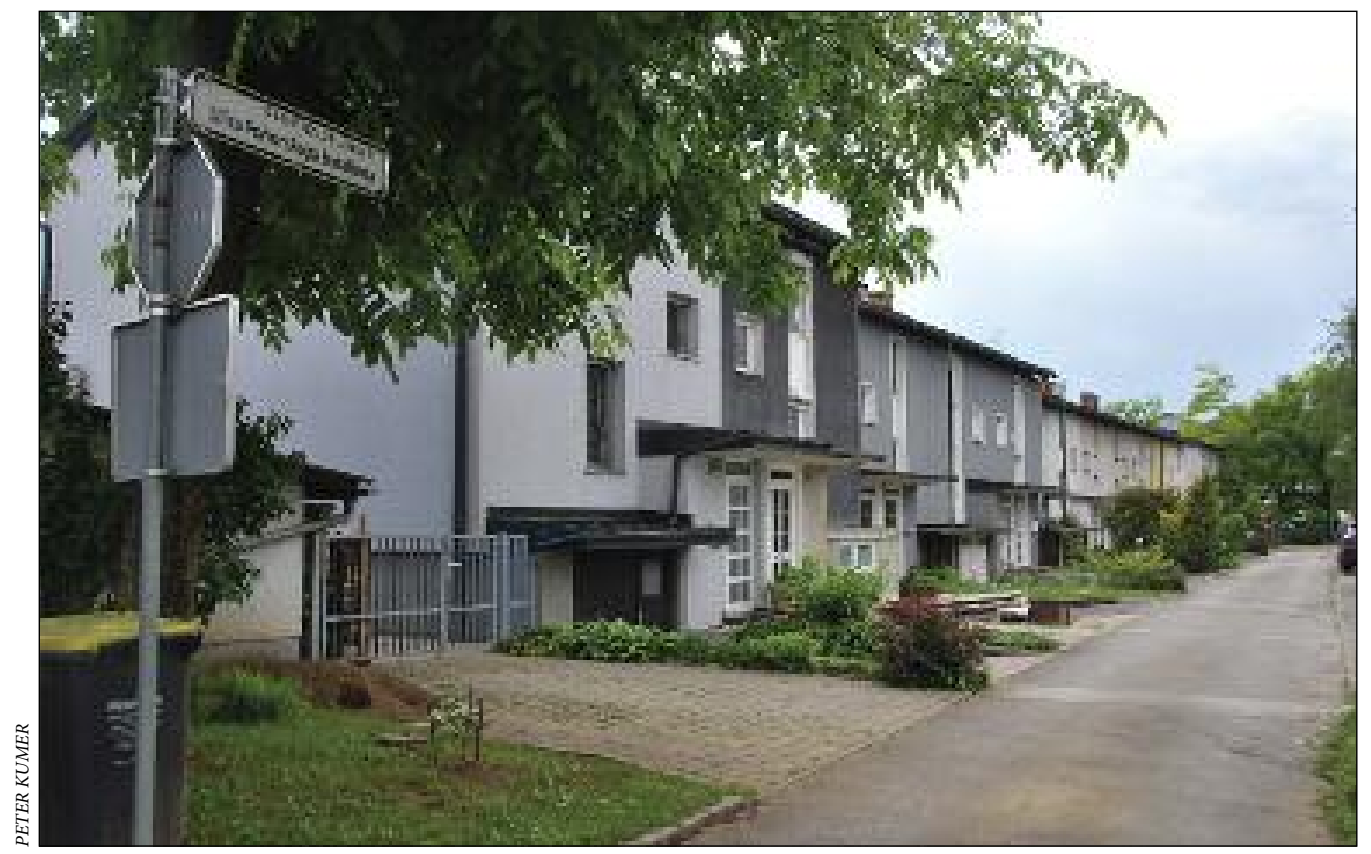

Slika 6: Vrstne hiše se največkrat pojavljajo v manjših karejih v ravni stavbni črti, kot na primer na Brinju za Bežigradom. 


\subsubsection{Atrijske in verižne hiše}

V tem morfološkem tipu prevladujejo pritlične atrijske hiše (slika 7) v obliki črke L z ograjenim vrtom, h kateremu so obrnjeni bivalni prostori, in verižne hiše, ki so v nasprotju od vrstnih hiš odmaknjene druga od druge in medsebojno povezane s pritličnimi objekti, v katerih so navadno pomožni stanovanjski prostori (Mihelič, Humar in Nikšič 2015). Nastanek atrijskih in verižnih hiš je spodbudil natečaj za enodružinsko hišo, ki je bil razpisan vzporedno z razstavo »Stanovanje za naše razmere« leta 1956. Na njem sta bila kot najpomembnejši tipološki novosti nagrajena projekta za enodružinsko hišo v nizu z ograjenim vrtom in projekt za pritlično hišo v obliki črke L (Mihelič 1983). Ta morfološki tip je močno povezan s prizadevanji za gradnjo hiš, ki bi prebivalcem omogočale visoko kakovost bivanja, ugodile želji po bivanju v enodružinski hiši z vrtom in hkrati dosegale racionalno izrabo zemljišča (Ivanšek 1988). Atrijske in verižne hiše so zgrajene po urbanističnem načrtu ter s sosednjimi stavbami tvorijo homogeno in urejeno celoto. Njihova gradnja je bila sprva omejena na manjše samostojne komplekse (na primer na Novinarski ulici za Bežigradom), od konca šestdesetih do začetka osemdesetih let so jih gradili v sklopu večjih stanovanjskih sosesk (na primer Murgle, Koseze, Dravlje) (Mihelič 1983), v sodobnosti pa se zopet pojavljajo na manjših območjih, zlasti na mestnem obrobju (na primer Tomačevo, Šmartno pod Šmarno goro).

\subsubsection{Območja meščanskih vil}

Območja meščanskih vil so poseben morfološki tip, ki je začel nastajati v zadnjem desetletju 19. stoletja. Prve vile so bile večstanovanjske in socialno mešane (na primer vila Wettach na Tomšičevi ulici),

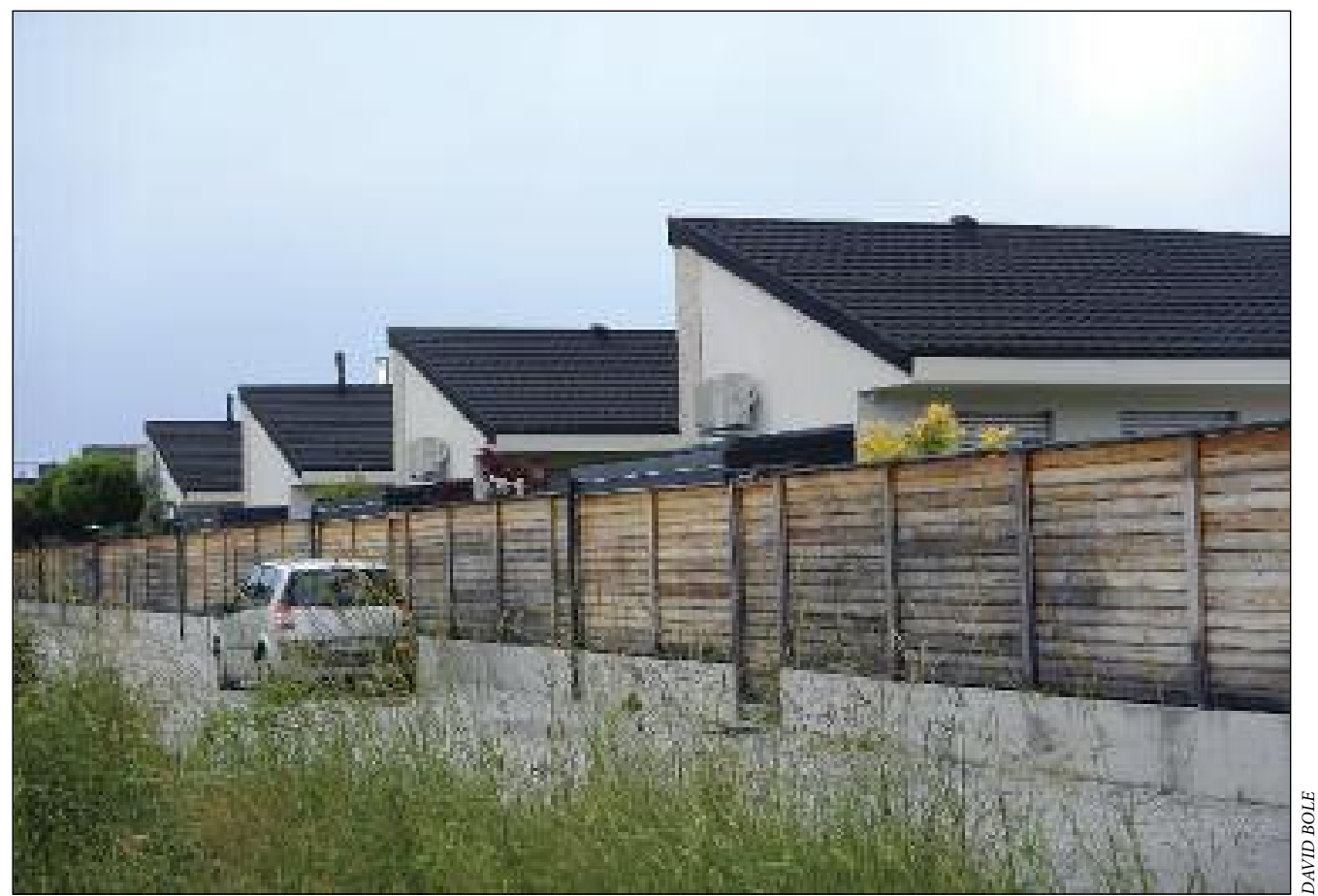

Slika 7: Atrijske hiše na Rudniku z obodno zazidavo zagotavljajo racionalno izrabo zemljišča in omogočajo visoko kakovost bivanja. 
poznejše, zgrajene v 20. in 30. letih prejšnjega stoletja, pa večinoma enostanovanjske. Vile sledijo različnim arhitekturnim slogom (historizem, secesija, funkcionalizem, modernizem), na splošno pa jih zaznamujejo razgibane fasade z zamiki in izzidki ter številni dekorativni stavbni členi (Drozg 2013; Režek Kambič 2015). Vile se glede na čas nastanka opazno razlikujejo po obliki strehe: vile, zgrajene po načelih historizma in secesije, imajo strmo in lomljeno streho, vile, zgrajene po načelih funkcionalizma in modernizma, pa ravno. Stavbe so praviloma postavljene sredi parcele, obkrožajo pa jih obsežna okrasna zelenica ali vrt in pomožni objekti. Območja meščanskih vil najdemo na obrobju mestnega središča: največje in najbolj razkošne so na Vrtači, v vzhodnem delu Rožne doline (slika 8) in na Mirju. Ob svojem nastanku so bile (in so še vedno) značilno socialnogeografsko območje s prevlado višjega srednjega in visokega družbenega razreda (Rebernik 2000). Vilska območja so v sodobnosti precej preobražena: ponekod nanje spominjajo le še posamezne hiše, številne vile pa so iz enostanovanjskih spremenjene v večstanovanjske hiše ali pa nimajo več stanovanjske rabe ( $\mathrm{v}$ njih so pogosto veleposlaništva).

\subsubsection{Urbanizirane vasi}

Ta morfološki tip obsega nekdanje vasi, ki so s prostorsko širitvijo mesta postale njegov del in so namesto obdelovalnih zemljišč skoraj v celoti obdane z novejšim mestnim tkivom. Funkcijsko in morfološko so večinoma močno preobražene. Na nekdaj prevladujočo kmetijsko dejavnost spominja vaški tloris, ki ga označujejo prostostoječa zazidava po načelu »posamič v gruči«, brez vidno določljivega reda, postavitev stavb ob prometnici na različen način (Drozg 1995), delno izoblikovano središče in (nekdanja) kmetijsko-gospodarska poslopja ob stanovanjskih hišah. Najbolj značilni primeri so Dravlje, Štepanja vas,

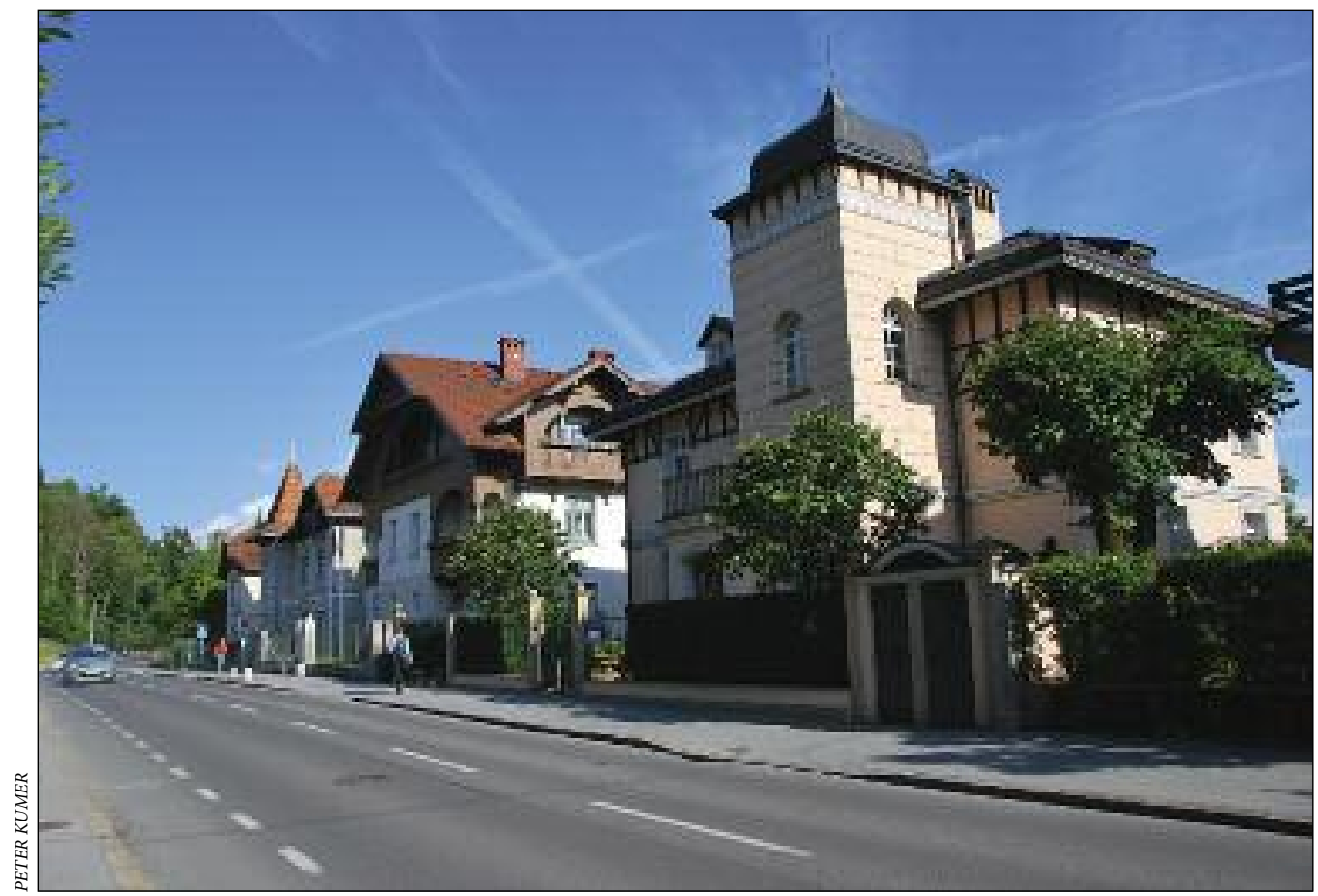

Slika 8: Rožna dolina je eno najbolj značilnih območij meščanskih vil, ki jih zaznamujejo razgibane fasade s številnimi izzidki. 


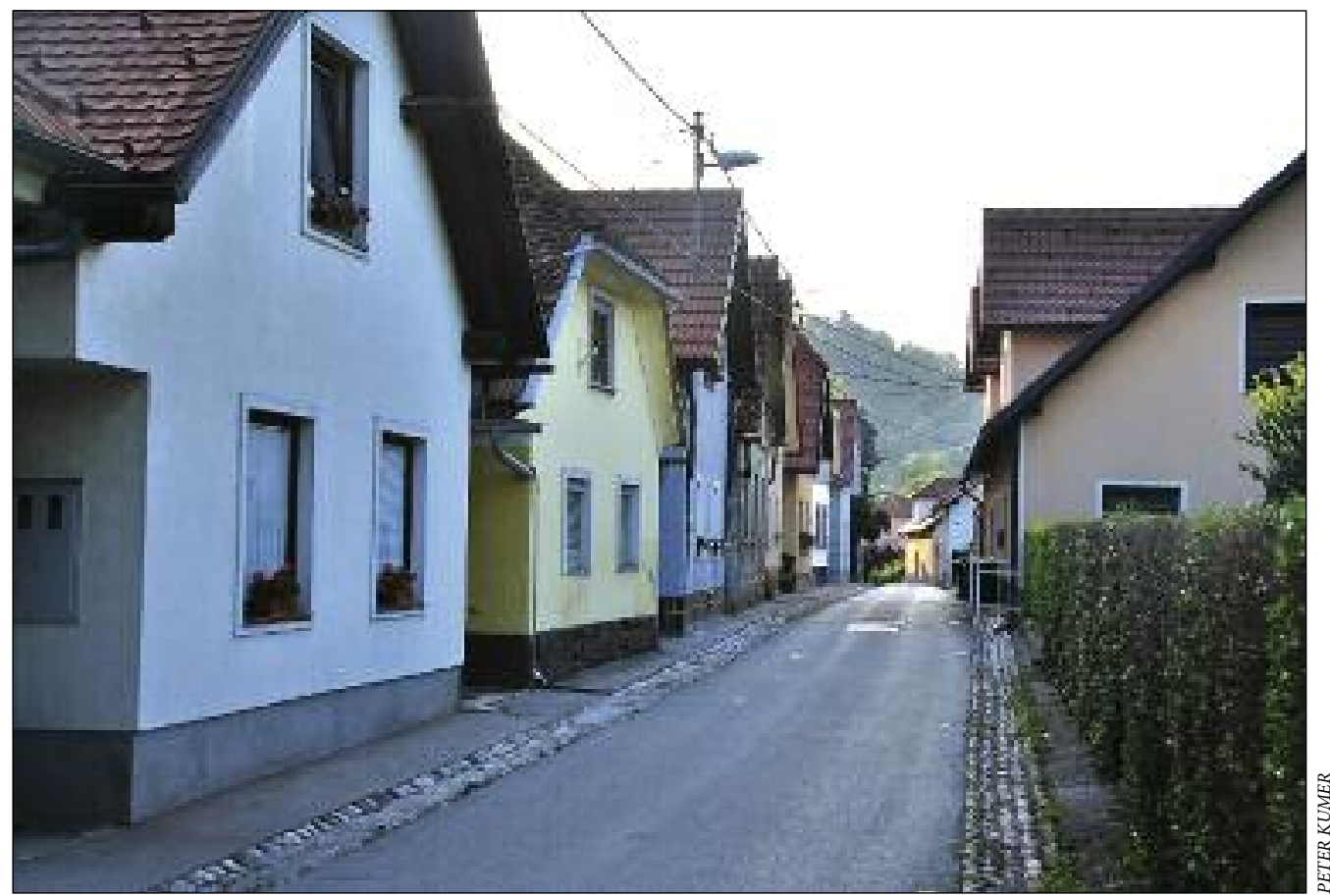

Slika 9: Krakovo ima ohranjeno srednjeveško parcelacijo in gabarite hiš.

Vič pri gostilni Žabar, Selo (ulica Mire Miheličeve) in Vižmarje. Večinoma prevladuje osrednjeslovenski tip kmečke hiše, ki je kombinacija alpske in panonske hiše, ki je značilno masivna, zidana s strmo dvokapno streho, širokimi napušči in velikimi okni (Drozg 1998a). Z drugimi gospodarskimi objekti navadno stoji v gruči. Na južnem obrobju Ljubljane se pojavlja sodobnejša različica barjanske kmečke hiše, pritlične pravokotno zidane hiše s frčado v mansardi in vzporedno postavitvijo glede na cesto. $\mathrm{V}$ ta morfološki tip smo uvrstili tudi nekdanji predmestji Krakovo in Trnovo, ki pa imata specifičen zazidalni sistem. To še posebej velja za Krakovo (slika 9), kjer stavbe stojijo tesno druga ob drugi, se s krajšo stranico držijo ceste, za hišami pa se razprostirajo dolgi vrtovi.

\subsubsection{Polurbanizirane vasi}

To so nekdanje samostojne vasi na obrobju Ljubljane, ki so $\mathrm{z}$ administrativno širitvijo Ljubljane in njenega vpliva kot zaposlitvenega središča postale njen del. V nasprotju od urbaniziranih vasi so funkcijsko in morfološko manj preobražene, večje po površini, obdane z obdelovalnimi zemljišči in še vedno živo kmetijsko dejavnostjo. Vaški tloris je dokaj dobro ohranjen, največkrat s prostostoječo zazidavo po načelu "posamič v nizu«: hiše so z daljšo ali krajšo (čelno) fasado obrnjene proti cesti in med seboj razmeščene v dokaj pravilnem redu (Drozg 1995). Ta morfološka območja imajo delno izoblikovano središče in številna kmetijsko-gospodarska poslopja ob stanovanjskih, relativno dobro ohranjenih kmečkih hišah. Največ morfoloških enot tega tipa je na vzhodnem obrobju Ljubljane. Njegovi najbolj tipični predstavniki so območja naselij na terasi reke Save na severu in severovzhodu Ljubljane (na primer Kleče, Savlje, Tomačevo (slika 10), Šmartno ob Savi, Jarše) ter naselij pod Golovcem na jugovzhodu (na primer Bizovik, Dobrunje, Sostro). Temu morfološkemu tipu smo prišteli tudi samostojne kmetije, ki jih prav tako najdemo na obrobju Ljubljane, prostorsko pa so precej razpršene. 


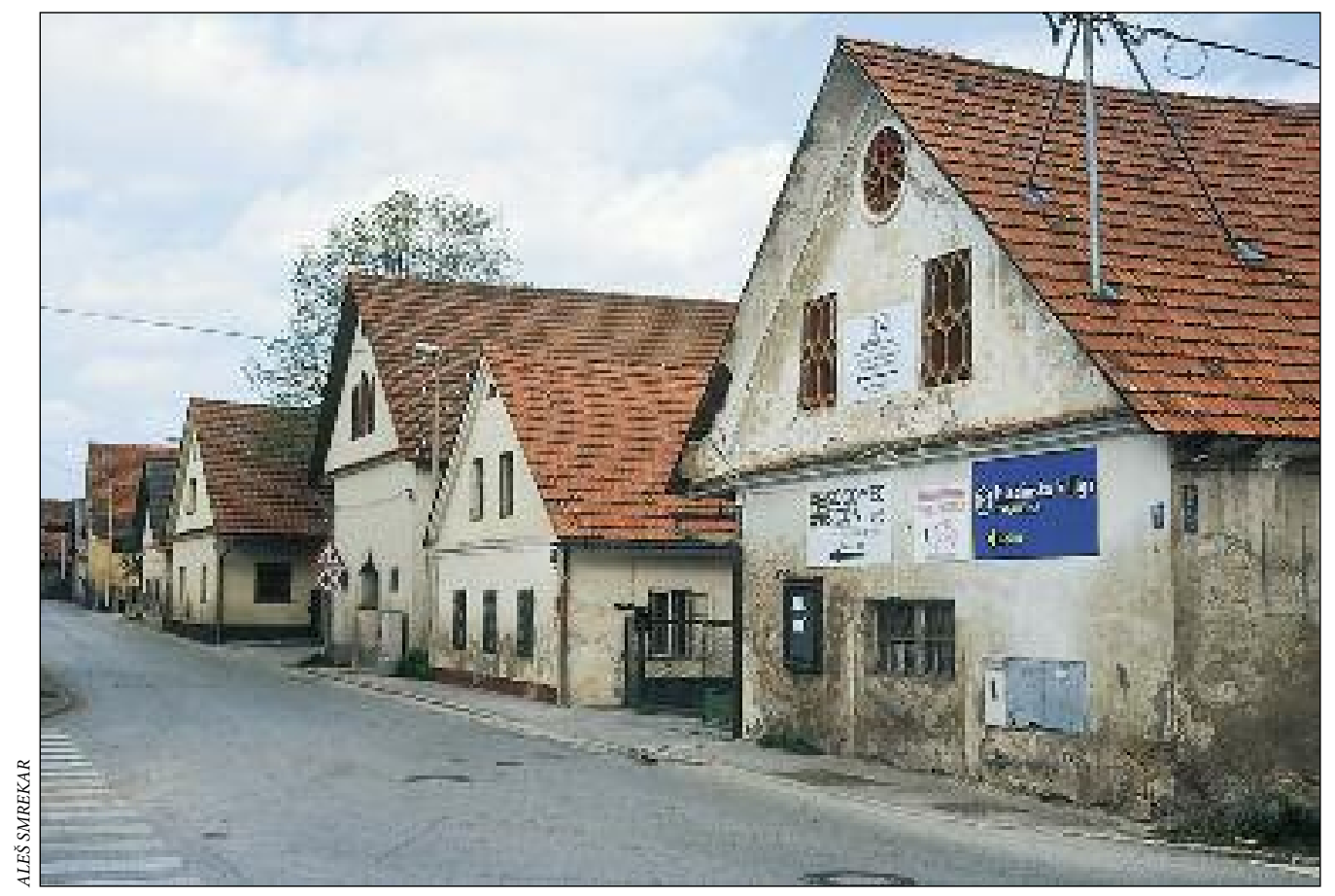

Slika 10: Tomačevo je tipična polurbanizirana vas $z$ dobro ohranjenim vaškim tlorisom.

\subsection{Območja večstanovanjskih hiš}

\subsubsection{Staro mestno središče}

Staro mestno središče je najstarejši del Ljubljane, ki se je razvil pod grajskim gričem na obeh bregovih reke Ljubljanice. Osrednji del tega morfološkega območja tvori »srednjeveška Ljubljana«, ki se je razvila vzdolž Starega in Mestnega trga na desnem bregu Ljubljanice (slika 11) ter Novega trga na njenem levem bregu in je bila od preostalega mesta vse do konca 18. stoletja ločena z obzidjem (Šarac 2013). Območje temeljno označujejo stare stavbe, saj so tri četrtine iz 19. stoletja ali starejše, in srednjeveški tloris: stavbe so razmeščene v vrsti, se držijo druga druge ter so $\mathrm{z}$ isto stranjo obrnjene proti ozki in obzidani prometnici. Zazidava je tako izredno strnjena. Prevladujejo večstanovanjske dvo- in trinadstropne stavbe, iz osnovnega gabarita pa izstopajo posamezne cerkve, palače in samostani. Večino stavb krasijo baročna pročelja in arkadna dvorišča. Zunaj mestnega obzidja so se na vse strani razraščala nekdanja predmestja (Karlovško, Poljansko, Šempetrsko in Kapucinsko predmestje, Gradišče) (Potočnik 1929). Predmestja imajo podoben parcelni vzorec in način zazidave kot srednjeveško jedro, po rušitvi obzidja pa so se z njim organsko zrasla. Čeprav so za predmestja značilne nižje, od eno- do dvonadstropne stavbe, smo jih s srednjeveškim jedrom združili v isti morfološki tip.

\subsubsection{Območje karejske zazidave mestnega središča}

Kot značilen morfološki tip smo označili predel Ljubljane, ki se je v drugi polovici 19. stoletja začel širiti zahodno in severno od srednjeveškega jedra do železniške proge. Največji pečat temu območju je dala urbanistična regulacija z mrežnim (ortogonalnim) sistemom razširjenih ulic, parkovnih površin in robno (karejsko) zazidavo (slika 12), ki se je še bolj uveljavila po velikem ljubljanskem potresu leta 1895 


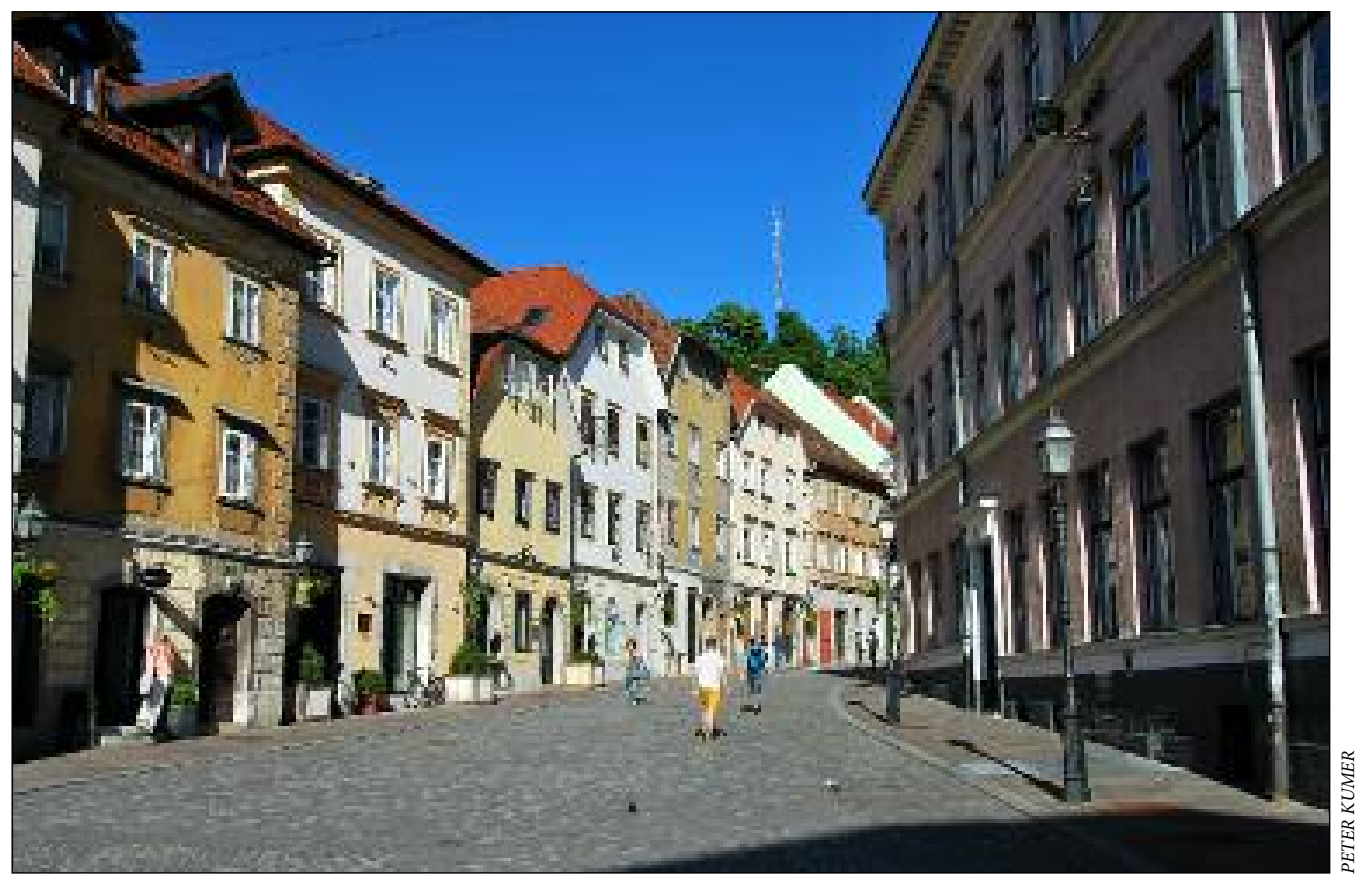

Slika 11: Gornji trg zaznamuje srednjeveški tloris z izredno strnjeno zazidavo.

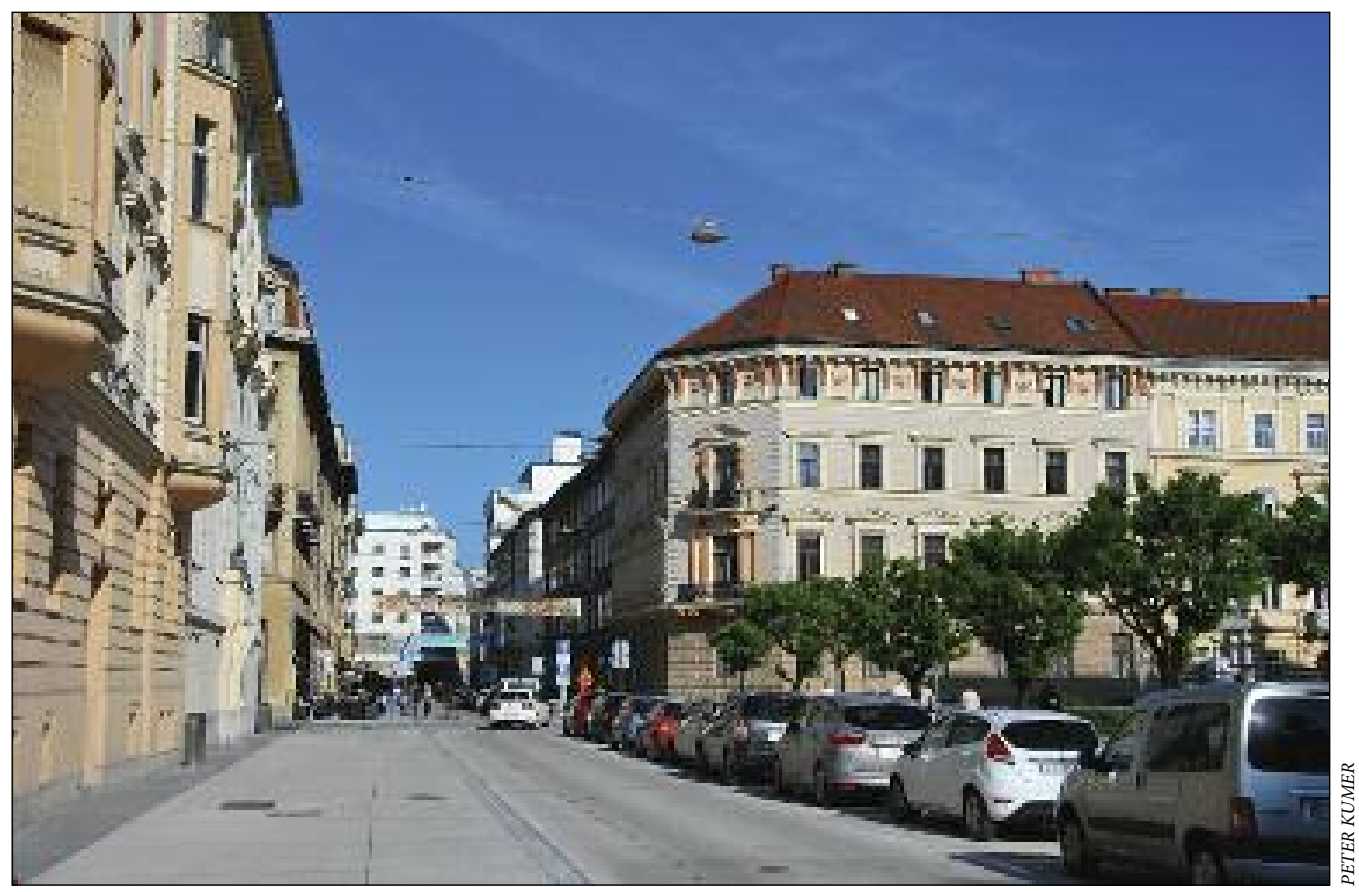

Slika 12: Območje karejske zazidave mestnega središča se ponaša z bogatimi arhitekturnimi slogi. 
(Mihelič 2010). Ulične bloke zapolnjujejo večnadstropne stavbe z bogato okrašenimi uličnimi fasadami, praviloma razdeljenimi v več horizontalnih pasov s poudarjenim vhodnim delom, $v$ različnih arhitekturnih slogih (neoklasicizem, neorenesansa, historizem, secesija), medtem ko so dvoriščne fasade oblikovane precej bolj funkcionalno, brez okrasja (Režek Kambič 2015). Po letu 1930 je zaznati vedno večji vpliv modernizma (stanovanjski blok Šahovnica na Vrtači, Mali nebotičnik na Igriški ulici), ki se kaže v prelomu s tradicijo, med drugim v poenostavitvi stavbne oblike in zmanjšanem številu ornamentov (Koselj 2010). Območje je pod močnimi modernističnimi vplivi nastajalo tudi po 2. svetovni vojni z izgradnjo novega poslovnega mestnega središča. V nekatere ulične kareje so se po letu 1960 »vrinile« tudi posamezne stanovanjske stolpnice (Štefanova, Kersnikova in Pražakova ulica). Z vidika značilnosti posameznih stavb gre za zgodovinsko, arhitekturno in morfološko raznoliko, a po prevladujoči karejski zazidavi prepoznavno območje, $v$ čigar nestanovanjskih poslopjih so danes najpomembnejše politične, upravne in kulturne funkcije v državi (na primer Državni zbor, ministrstva, sodišča).

\subsubsection{Nekdanja predmestja večstanovanjskih hiš}

V času, ko se je začelo oblikovati novo mestno središče, so začela rasti in se mestu priključevati tudi bližnja predmestna naselja, ki so v nasprotju od nekdanjih predmestnih vasi zrasla ob vseh pomembnejših ljubljanskih vpadnicah. Njihovi zametki so nastali že v srednjeveškem obdobju, ko so se vanje naseljevali pretežno obrtniki, njihovo širitev pa je spodbudil prvi sunek industrializacije v drugi polovici 19. stoletja (Novak 1991). Industrijski obrati, kot so Tobačna tovarna, Pivovarna Union ali Mestna klavnica, so se umeščali na prometno dobro dostopna območja v neposredno bližino mestnega središča. Zaradi reševanja stanovanjskega problema delavcev jim je sledila izgradnja dvo- do trinadstropnih večstanovanjskih poslopij bodisi v obliki karejev (Tabor, Ilirski bloki v Spodnji Šiški) bodisi v obliki posameznih robnih, ponekod tudi nižjih, enonadstropnih stanovanjskih hiš v strnjeni zazidavi ali modificiranih

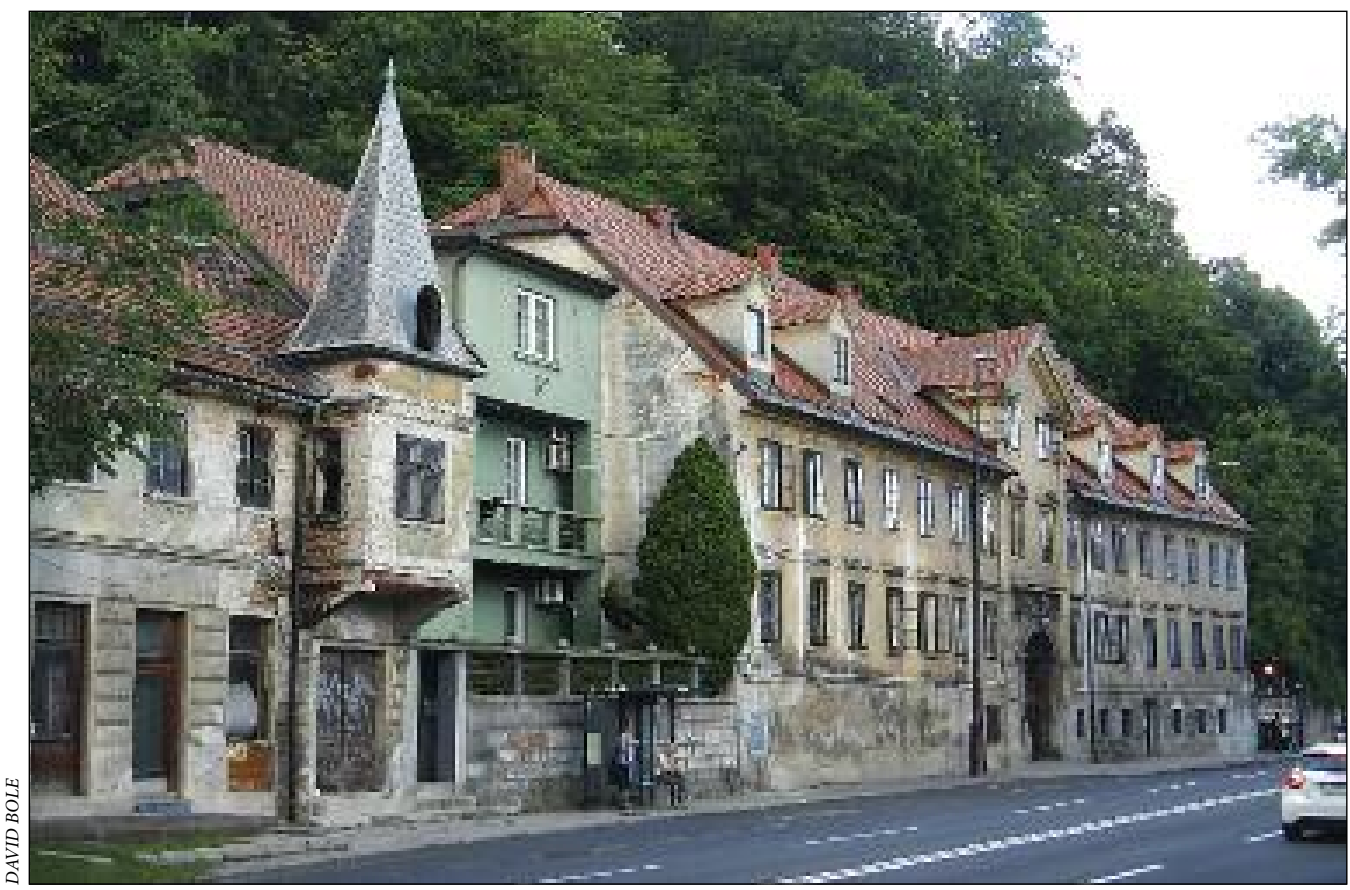

Slika 13: Značilna obulična strnjena zazidava ob Karlovški cesti, nekoč pomembni mestni vpadnici. 
kmečkih hiš ob mestnih vpadnicah (Celovški, Tržaški, Karlovški (slika 13) in Poljanski cesti), ki so zapolnile prostor proti mestnemu središču. Čeprav so do današnjih dni nekatere stavbe porušili, so ostanki teh predmestij dokaj dobro ohranjeni ter večina teh stavb, kljub dotrajanosti in slabi kakovosti bivalnega okolja, še danes ohranja svojo bivalno funkcijo.

\subsubsection{Delavske kolonije}

Večstanovanjskim stavbam ob vpadnicah so v obdobju industrializacije sledile delavske kolonije (slika 14). Tudi te so bile umeščene v bližino industrijskih in drugih obratov. Nekatere kolonije so nastale spontano, brez prave urbanistične zasnove na močvirnatih in za gradnjo manj primernih zemljiščih (na primer v Sibiriji) ter so bile v času nastanka barakarska naselja $\mathrm{z}$ zelo slabimi bivalnimi razmerami, brez vodovoda in kanalizacije (Vogelnik 1938). Nekatere kolonije so gradile zadruge za delavsko prebivalstvo, zato se omenjajo tudi kot zadružne kolonije (Dimitrovska Andrews, Mihelič in Stanič 2001). Že njihova imena nakazujejo razlog njihovega nastanka, na primer Carinarniška kolonija ob Vilharjevi cesti, Železničarska kolonija v Zeleni jami in Hranilniška kolonija na Hranilniški ulici. Morfološko gre za večstanovanjske eno- in dvonadstropne stavbe, postavljene v uličnem nizu, ki skupaj tvorijo arhitekturno-urbanistično celoto. Njihova zunanja oblika je preprosta, v tlorisu pravokotna s pogosto prizidanimi prostori za shranjevanje drv, naprav in strojev. Strehe so krite z opeko, zidovi so masivni, $\mathrm{z}$ dvodelnimi okni, vrata $\mathrm{v}$ hišo vodijo $\mathrm{z}$ dvoriščne strani (Batista 2010). Po morfoloških značilnostih so drugačne kolonije štiristanovanjskih pritličnih "zasilnih « hiš na Gerbičevi ulici, Ob Ljubljanici in Samovi ulici, ki so nastale kot nadomestna socialna gradnja za barakarska naselja (Zupančič 2005). Nekatere kolonije so zaradi raznovrstnih posegov lastnikov v sodobnosti močno preobražene. Enostanovanjske delavske kolonije, ki so arhitekturno tudi najbolj kakovostne (na primer vrtna kolonija prostostoječih

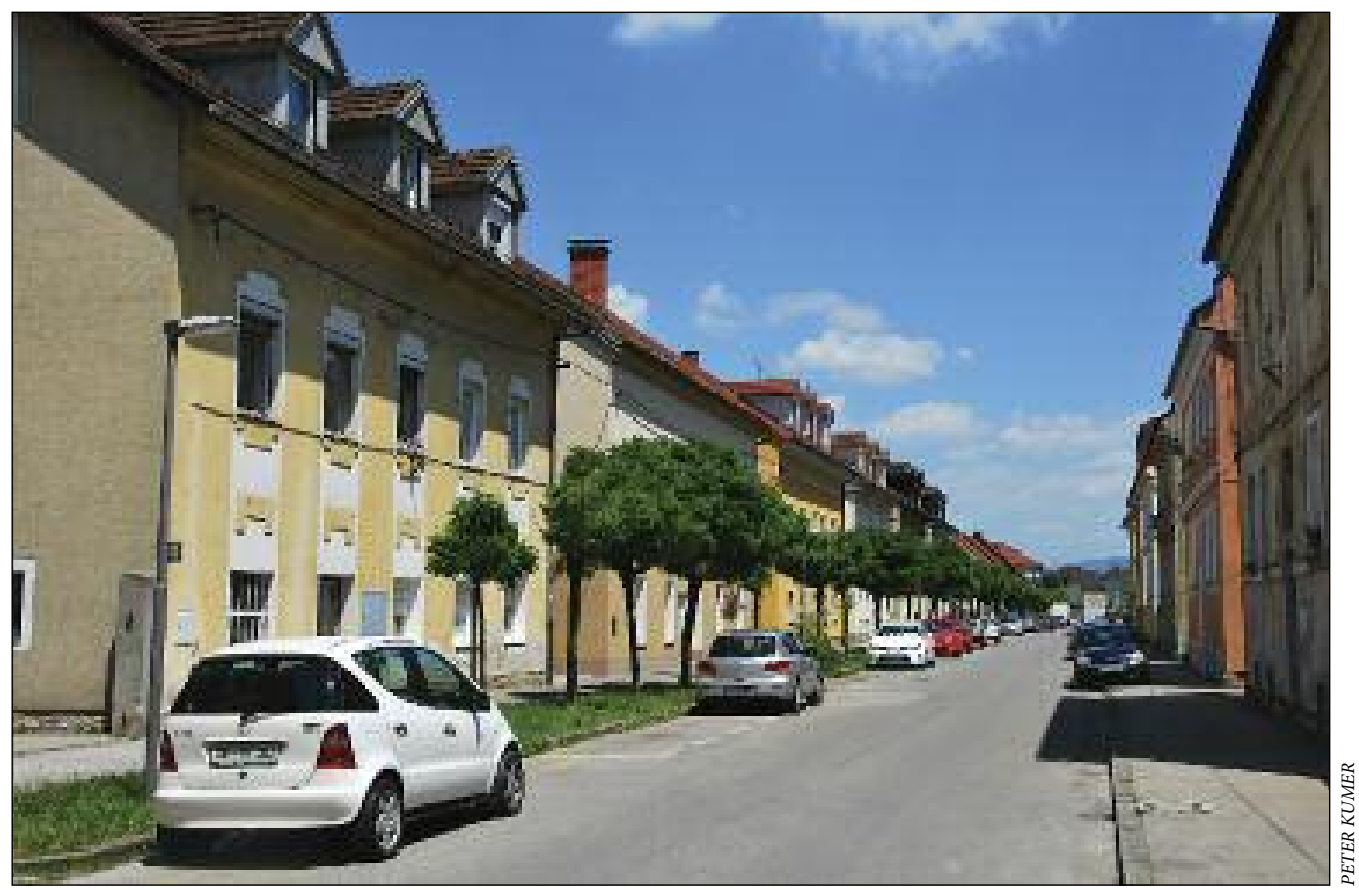

Slika 14: Delavska kolonija na Ulici Vide Pregarčeve je nastala med letoma 1920 in 1940 ter je eden izmed najbolj ohranjenih primerov tega morfološkega tipa $v$ Ljubljani. 
hiš stanovanjske zadruge Stan in dom ter vrstne hiše Vzajemne zavarovalnice ob Dermotovi ulici), smo uvrstili v drug morfološki tip.

\subsubsection{Medvojne večstanovanjske hiše}

V ta tip uvrščamo velike večstanovanjske hiše, zgrajene med 20. in 40. leti 20. stoletja. Gre za kolektivno najemniško stanovanjsko gradnjo, ki se je pojavila kot odgovor na medvojno pomanjkanje stanovanj. Dejansko so bila zgrajena le maloštevilna, na manjših, prostorsko razdrobljenih območjih (Mihelič 1983). Za prvi takšen primer velja Meksika na Njegoševi ulici (slika 15), obsežna večstanovanjska stavba v karejski zazidavi, zgrajena okoli osrednjega dvorišča po vzoru dunajske socialne stanovanjske gradnje. Morfološko podobna je tudi »Rdeča hiša « na Poljanski cesti, ki ima na severni strani dodana dva trakta. V ta morfološki tip uvrščamo tudi tako imenovane Dukićeve bloke, ki so z bloki, razporejenimi ob robovih stavbnega otoka še vedno bližje klasični obodni zidavi, posamezne večstanovanjske stavbe, večinoma v obcestni zazidavi ob Dunajski in Celovški cesti (na primer Galetov blok) ter Fondove bloke za Bežigradom, prvo stanovanjsko naselje prostostoječih blokov v Ljubljani. Morfološki tip ima po arhitekturno-urbanistični zasnovi značilnosti zgodnjega funkcionalizma.

\subsection{Območja eno- in večstanovanjskih hiš}

Območja brez razpoznavnega tlorisa s prepletom eno- in večstanovanjskih stavb, kjer delež enih ali drugih ni večji od $75 \%$, smo opredelili kot poseben morfološki tip (slika 16). Zazidava praviloma ne sledi geometričnim vzorcem, razvidni sta stihijska gradnja in preplet stavb iz različnih zgodovinskih obdobij. Za nekatera območja je v zadnjih desetletjih značilno tudi spreminjanje enostanovanjskih

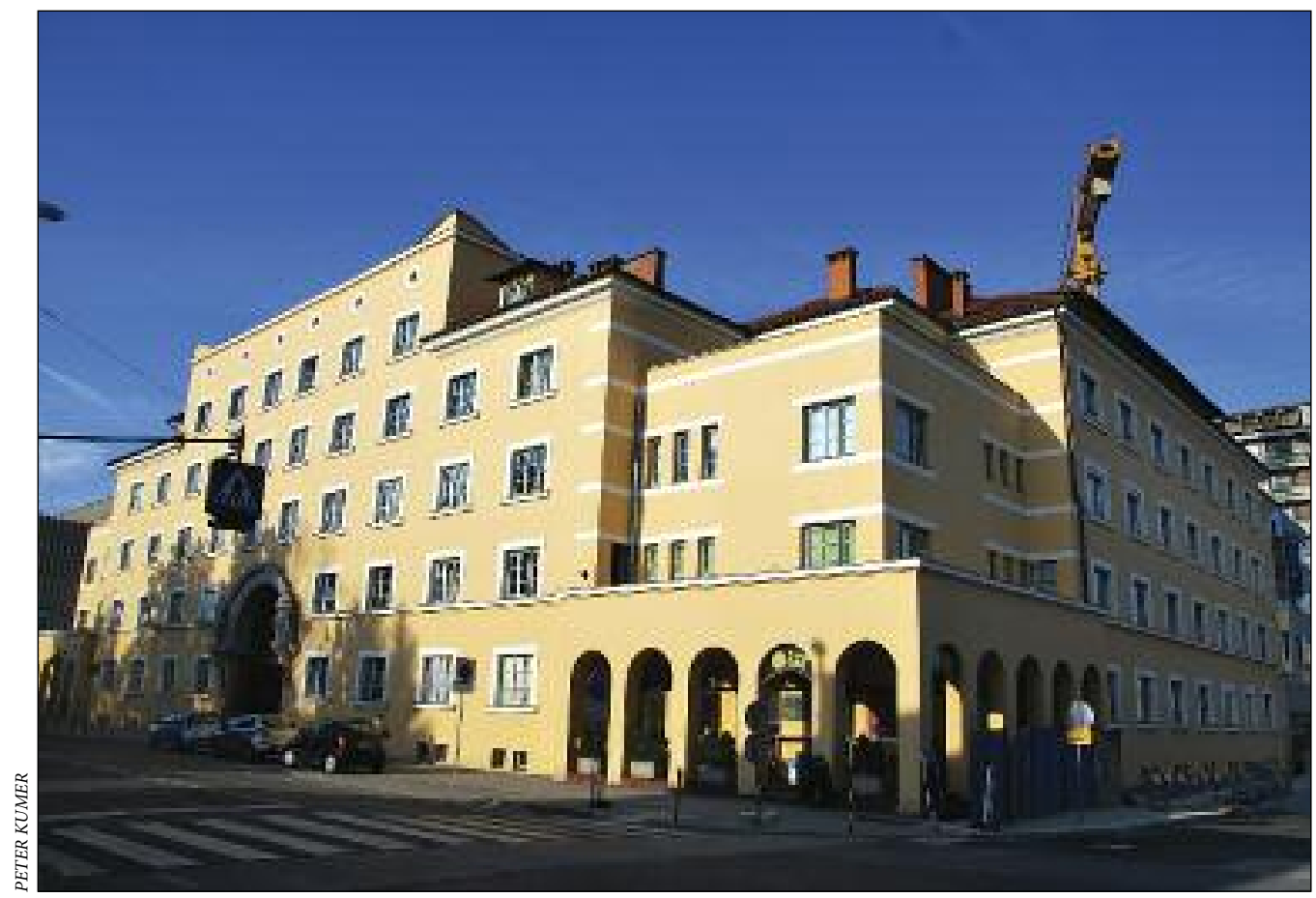

Slika 15: Mogočna Meksika je prvi primer medvojne kolektivne stanovanjske gradnje v Ljubljani. 


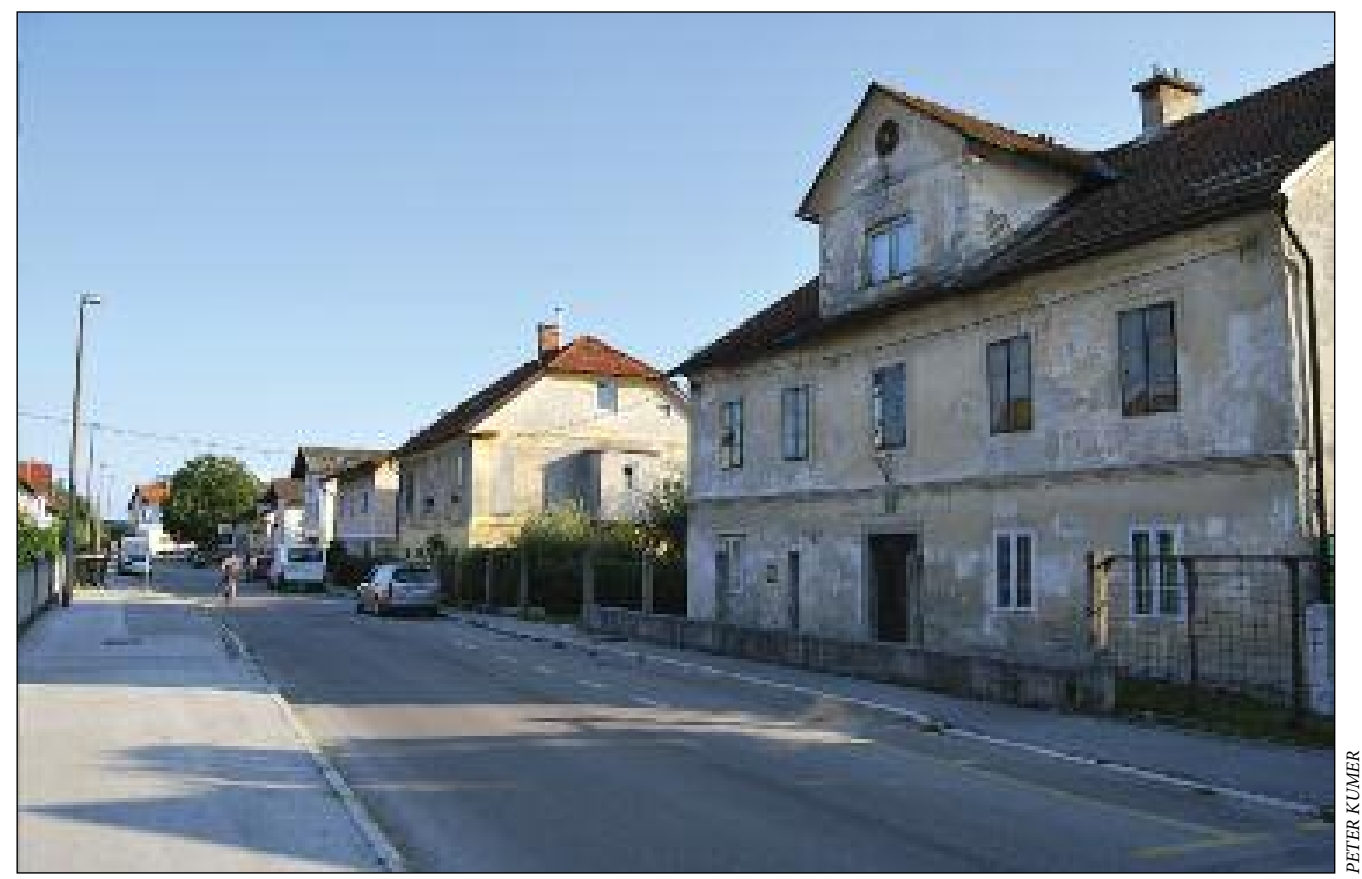

Slika 16: Najbolj »mešan « in nepregleden morfološki tip označuje preplet eno- in večstanovanjskih stavb iz različnih zgodovinskih obdobij, kot na primer na Cesti na Loko.

hiš v večstanovanjske. Približno polovica stavb je nastala pred 2. svetovno vojno, pogoste so nekdanje kmečke hiše. Okrog polovico stavb predstavljajo prostostoječe enostanovanjske hiše, četrtino večstanovanjski objekti, preostalo četrtino pa vrstne, dvostanovanjske ali bivanjsko opuščene stavbe. Največ teh območij je ob mestnih vpadnicah (Celovški, Dunajski ali Tržaški cesti) ali na »robnih« in za bivanje manj primernih območjih, na primer na obrobju Ljubljanskega barja ter pod vzpetinami Grajskega hriba, Golovca in Šišenskega hriba. Na teh območjih se pogosto prepletata stanovanjska in nestanovanjska raba. Tako se na Dolgem mostu ob Tržaški cesti poleg kmečkih hiš izpred 2. svetovne vojne pojavljajo nove mestne stanovanjske hiše iz 60 . let, vmesni prostori pa se zapolnjujejo $\mathrm{z}$ manjšimi trgovskimi in poslovnimi stavbami, v zadnjem desetletju tudi z večstanovanjskimi hišami oziroma manjšimi vila bloki.

\subsection{Območja blokovske gradnje}

\subsubsection{Povojna blokovska gradnja}

V tip povojne blokovske gradnje uvrščamo območja stanovanjskih blokov, stolpičev in stolpnic, ki so bili zgrajeni med letom 1945 in približno sredino 60. let 20. stoletja. V prvem desetletju po vojni so stanovanjska naselja gradili v neposredni bližini tovarn po predvojnih funkcionalističnih vzorcih. Značilen stavbni tip je tipiziran, podolgovat, od dvo- do štirinadstropen prostostoječi stanovanjski blok, postavljen v smeri zemljiške parcelacije v smeri sever-jug (Mihelič 1983). Edini večji takšni blokovski naselji sta bili Litostroj, naselje za tovarniške delavce, in poleg njega naselje mestnega ljudskega odbora ob Celovški. Bolj pogosta so bila manjša območja blokov in štirinadstropnih stolpičev, ki so bila prostorsko razdrobljena (na primer Bičevje, Drenikova ulica, Šišenska cesta in Prule). Posebnost sta najstarejše slovensko študentsko naselje v Rožni dolini in Savsko naselje (slika 17), ki sta nastajali postopoma. Zametki 


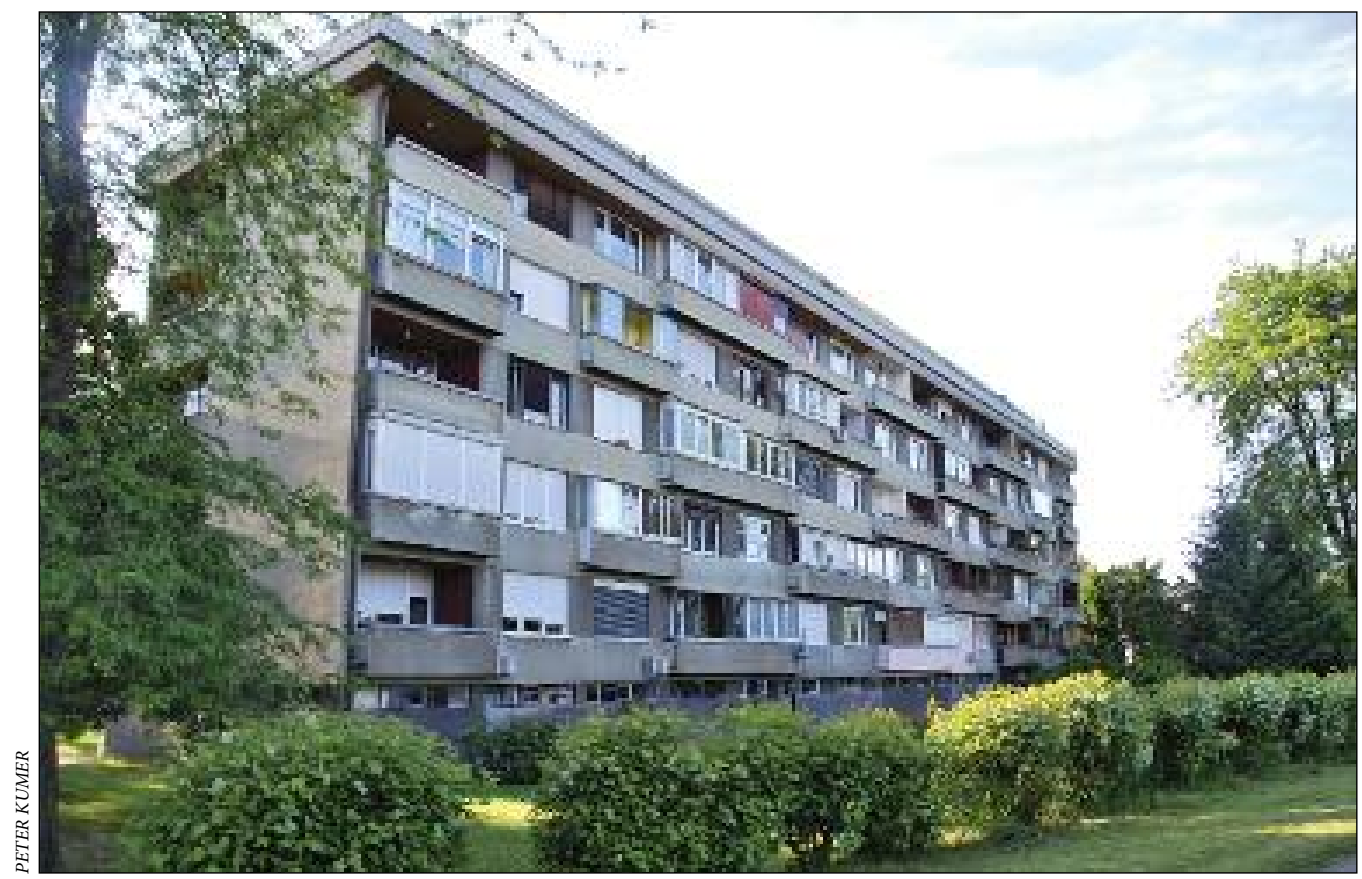

Slika 17: Za povojno blokovsko gradnjo je najbolj značilen podolgovat, štirinadstropen prostostoječi stanovanjski blok (primer je iz Savskega naselja).

Savskega naselja segajo v čas takoj po 2. svetovni vojni, ko so bile zgrajene enonadstropne večstanovanjske hiše, pozneje pa se je intenzivno dograjevalo z različnimi stavbnimi tipi, tudi s stanovanjsko stolpnico, ki se je v Slovenijo razširila s Švedske. V Ljubljani so jih prvič zgradili konec 50. let v Roškem naselju, nato v Savskem naselju, pozneje pa povsod, kjer so nastajale vrzeli zaradi podiranja starih hiš. Gradnja posamičnih stolpnic je bila pogosto predmet kritik, saj so jih ponekod nasilno vrinili v mestno silhueto ali postavljali brez jasnega urbanističnega koncepta (Mihelič 1983).

\subsubsection{Blokovske stanovanjske soseske}

S kritikami prvih povojnih stanovanjskih naselij in pod močnimi skandinavskimi vplivi se je postopoma uveljavil koncept stanovanjske soseske, ki je z Generalnim urbanističnim planom leta 1965 postala temeljna organizacijska oblika mestne zgradbe (Malešič 2015). Osnovni značilnosti tega koncepta sta razdelitev soseske na četrti in sosedstva ter zazidava $\mathrm{z}$ različnimi stavbni tipi: a) stolpnice ob prometni žili, b) nižji prostostoječi bloki, bogato ozelenjeni ter opremljeni z otroškimi igrišči in sprehajalnimi potmi ter c) niz enostanovanjskih hiš (Mihelič 1983). Za prvi preizkus tega teoretičnega modela velja BS 6 na Brinju, ki pa se po oblikovnih značilnostih stavb ne razlikuje od povojne blokovske gradnje. Prvi urbanistično-arhitekturno bolj ambiciozno zasnovani soseski sta ŠS 6 v Šiški iz konca 60. let in BS 7 (Ruski car) za Bežigradom iz 70. let 20. stoletja. Najbolj opazni morfološki novosti sta tako imenovana lamelna zasnova stolpnic in blokov v obliki črk U, I, L in Z, ki oklepajo zelenice in otroška igrišča (Rozin Šarec s sodelavci 1976) ter uporaba bolj tradicionalnih morfoloških oblik v tlorisnih zasnovah, kot so ulica, trg in zaprt stavbni blok. Koncept zazidave na osnovi zaprtega ali polzaprtega stavbnega bloka artikulira intimni prostor naselja, povečuje zasebnost in razbija monotonost. Ponovljen je bil v različnih inačicah: nekatera območja odsevajo težnjo po znižanju višinskega gabarita, manjši gostoti stanovanj, 
Slika 18: Soseska BS 3 je tipičen primer stanovanjske soseske, ki jo sestavljajo stolpnice ob prometni cesti ter nižji stanovanjski bloki v lamelni zasnovi.

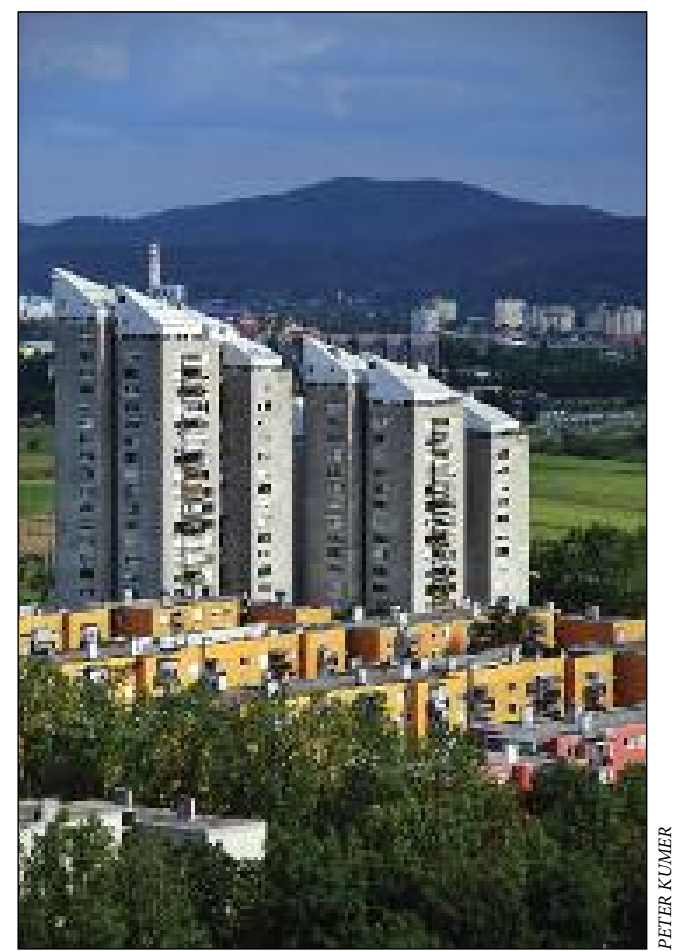

izboljšanju njihove kakovosti in večanju stanovanjske površine (na primer VS 4, Draveljska gmajna, BS 3; slika 18), za nekatera pa je značilna velika gostota stanovanj (nad 200 prebivalcev/ha) in višji gabarit stavb (na primer Trnovo, Štepanjsko naselje, Nove Fužine). Kot tipološka novost se sredi 70. let pojavi terasasti blok, ki združuje prednosti stanovanjskega bloka in enostanovanjske hiše (zgrajen v Kosezah). Nasploh blokovske stanovanjske soseske v primerjavi s povojno blokovsko gradnjo označujeta večja kakovost in privlačnost bivalnega okolja (Mihelič 1983).

\subsubsection{Sodobna blokovska gradnja}

V 80. letih 20. stoletja je ideja stanovanjske soseske kot temeljne organizacijske oblike mestne zgradbe postopoma zamrla. Prehod iz planskega v tržno gospodarstvo leta 1991 je zaradi vpliva zasebnega kapitala prinesel spremembe tudi v načinu gradnje, ki so se nakazovale že konec 80. let z zazidalnim načrtom Zupančičeve jame, edinega primera postmodernističnega urbanizma v Ljubljani (Černigoj 2015). Pojavi se sodobna blokovska gradnja, ki jo na splošno zaznamujejo velika izkoriščenost stavbne parcele (velik delež prometnih ter majhen delež odprtih in zelenih površin), majhni razmiki med stavbami, zelo razgibane fasade s številnimi izzidki in iztoki ter sodobni materiali, kot sta kovina in steklo (Gazvoda 2001; Drozg 2007; Bole 2015). Zaradi visoke cene zemljišč so sodobni bloki grajeni na manjših površinah, pogosto na nekdanjih degradiranih območjih - nekdanje vojašnice, industrijska območja in sive cone (Rebernik 2007). Sodobno blokovsko gradnjo označujejo različni morfološki tipi; najbolj pogost je vila blok, dva- do štirinadstropna stavba navadno kvadratnega tlorisa $\mathrm{z}$ manjšim številom stanovanj v nadstropju (Čerpes, Blejec in Koželj 2008; Mihelič, Humar in Nikšič 2015), ki se pojavljajo posamično (na primer Vila Grad ob Roški cesti, Kondominij Trnovski Pristan) ali znotraj večjih stanovanjskih sosesk (na primer Polje 1, 2 in 3, Bežigrajski dvor, Nove Poljane), ponekod tudi v kombinaciji 


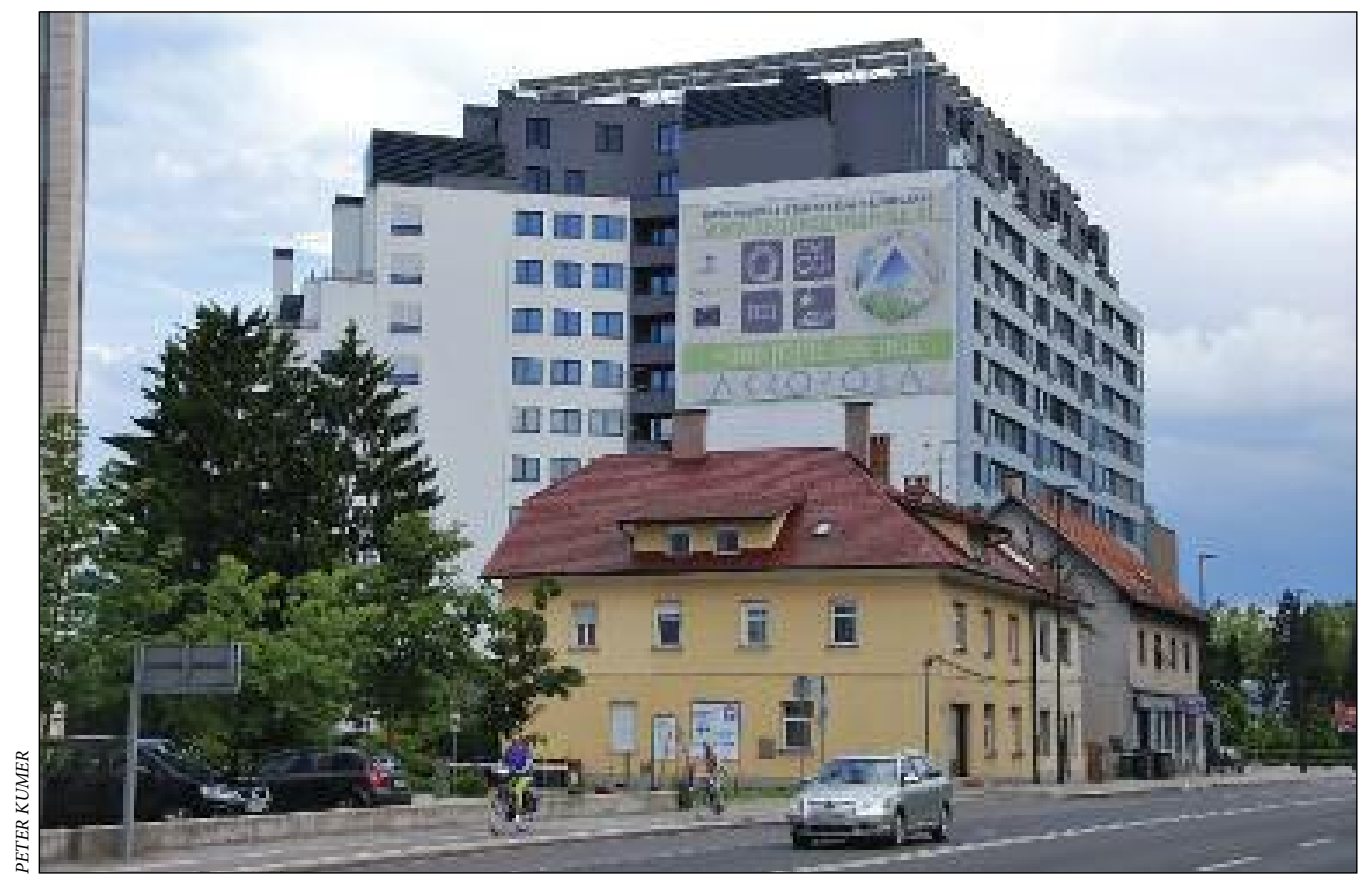

Slika 19: Eko srebrna hiša je primer sodobne megastrukture, s katero so zapolnili prazno zemljišče ob Dunajski cesti. Zaznamujeta jo velika gostota stanovanj in pomanjkanje javnih zelenih površin.

$\mathrm{z}$ večjimi bloki $\mathrm{v}$ obcestni zazidavi in manjšimi v prostostoječi (Zelena jama). Znotraj tega morfološkega tipa ločimo tudi neomodernistične prostostoječe bloke (na primer soseska Zeleni gaj na Brdu, del Mosteca), komplekse objektov izjemno velikih dimenzij (megastrukture), kot so Celovški dvori, Eko srebrna hiša (slika 19) ali Trnovska vrata ter območja novejše karejske zazidave v mestnem središču (Kotnikova, Trubarjev kvart). Nekatera območja sodobne blokovske gradnje so morfološko unikatna, kot na primer stavba R5 nekonvencionalne trikotne oblike v južnem delu Zupančičeve jame, ki se jo je prijelo ime "Skakalnica«, terasasti vila bloki v Podborštu v Črnučah ali območja prekinjene obodne zazidave z objekti v obliki črke U (Nova Grbina).

\section{Razprava}

Med postopkom tipiziranja smo naleteli na številne izzive, ki jih ni bilo vedno mogoče nedvoumno rešiti. Prvi je bil določitev posameznih morfoloških tipov ob upoštevanju postavljenih izhodišč; pazili smo, da bo število tipov tolikšno, da bo tipologija pregledna, razumljiva in hkrati ne preveč poenostavljena. Z vidika heterogenosti morfoloških tipov izpostavljamo območja blokovske gradnje; znotraj njihovih posameznih tipov tako lahko ločimo dodatne podtipe, ki se razlikujejo glede na obliko oziroma stavbno tipologijo, a njihova podrobnejša obravnava presega namen tega članka. Kljub temu pa smo za vsak morfološki tip prepoznali skupne morfološke značilnosti, ki jih ločujejo od drugih tipov.

Pri ravni natančnosti smo skušali biti čim bolj dosledni, vendar pa to ni bilo vedno mogoče ali smiselno. Nekatere morfološke oznake tako v celoti veljajo za posamezno morfološko enoto (zlasti območja blokovske gradnje, vrstne hiše), nekatere pa za njen pretežni del (zlasti območja prostostoječih enostanovanjskih hiš, (pol)urbanizirane vasi). Nekatera tovrstna območja so morfološko zelo heterogena 
oziroma jih tvorijo stavbe različne oblike in starosti, zato raven obravnave na ravni posamezne stavbe ni bila smiselna ter je bila potrebna večja stopnja generalizacije. S tem so povezana tudi nekoliko ohlapnejša poimenovanja morfoloških tipov.

Poseben izziv je predstavljalo uvrščanje posameznih enot v morfološke tipe. Tako je bilo nekatera območja meščanskih vil zelo težko ločiti od starejših območij enostanovanjskih hiš, saj so izrazito preobražene in stavbno izredno raznolike. Enako velja za razlikovanje med novejšimi in starejšimi območji prostostoječih enostanovanjskih hiš, v slednjih je namreč tipičnih starejših mestnih hiš ponekod le še za vzorec. V nekaterih primerih smo naleteli na dilemo, ali slediti zgodovinskemu ali oblikovnemu kriteriju: tako bi vrstne hiše na Dermotovi ulici po času in okoliščinah nastanka lahko uvrstili tudi med delavske kolonije. Urbanistično-arhitekturni koncepti, ki so vplivali na stanovanjsko gradnjo, so se mnogokrat precej prekrivali, zato je bilo nekatera območja zelo težko nedvoumno uvrstiti v en morfološki tip. Izmed takšnih primerov izpostavljamo stanovanjsko sosesko Brinje, ki je po obliki stavb bližje povojni blokovski gradnji, po urbanistični zasnovi pa konceptu stanovanjske soseske, in Savsko naselje, ki ima danes vse elemente stanovanjske soseske, a se je dograjevalo postopoma, prevladujoči stavbni tipi pa imajo značilnosti takojšnjega povojnega obdobja.

Treba je poudariti, da je vsak poskus morfološke tipizacije zelo kompleksna naloga. Omenili smo že, da so tovrstne raziskave nujno regionalno pogojene, njihova univerzalnost, splošna veljavnost ter teoretska in metodološka verodostojnost pa je omejena. Pričujoča morfološka tipologija Ljubljane, v kateri morfološko zgradbo razumemo v nekoliko širšem, geografskem kontekstu, ne samo kot obliko posameznih stavb, pač pa tudi njihovih pripadajočih ulic ali sosesk, zato ni edina pravilna. Enako velja tudi za poimenovanja morfoloških tipov. Zavedamo se, da ni nujno, da bo sprejeta tudi v drugih strokah ali med drugimi avtorji, ki imajo na morfološko zgradbo drugačne poglede.

Za konec razprave navajamo še kritičen pretres morfološke zgradbe in preteklega mestnega razvoja. Tako kot večina mest je tudi Ljubljana po svoji morfološki zgradbi specifična. Posamezna morfološka območja so v povprečju dokaj majhna in prostorsko razdrobljena; nekatera niso homogena, temveč so preplet različnih stavbnih tipov, v katerih se zrcalijo različna zgodovinska obdobja. Ob prostorski rasti mesta je na primer prišlo do spajanja $\mathrm{z}$ vaškimi naselji ob glavnih mestnih vpadnicah, kar ugotavljajo tudi drugi avtorji (Turk Niskač, Klaus in Starec 2010). Pomemben element današnje podobe Ljubljane so zato tudi ostanki vaških jeder in kmečkih hiš v neposredni bližini mestnih vpadnic in blokovskih stanovanjskih sosesk, na primer v Spodnji Šiški, Štepanji vasi in Vodmatu. Naštete posebnosti niso nujno nekaj slabega, saj predstavljajo protiutež tako imenovanemu generičnemu urbanizmu (Milič 2006), posledični izgubi avtentičnosti in vedno večji podobnosti z ostalimi mesti (Zukin 2010). Z analizo morfološke zgradbe smo potrdili, da se ljubljansko mestno tkivo v zadnjih nekaj desetletjih postopoma preobraža in izgrajuje navznoter, zlasti s sodobno blokovsko gradnjo na manjših prostih površinah in degradiranih urbanih območjih. Takšen razvoj je skladen s paradigmo trajnostnega urbanega razvoja (kljub pomanjkanju zelenih površin zaradi visokega koeficienta izrabe zemljišča), vendar lahko ogrozi razpoznavnost mestne zgradbe, ki je po mnenju Dimitrovske Andrews, Miheličeve in Staniča (2001) že zdaj precej načeta zaradi slabega fizičnega stanja stavb ob vpadnicah, stihijske zazidave na južnem obrobju mesta, vizualno neurejenostjo in heterogenostjo posameznih območij ter neprimernim poseganjem v vaška jedra. V tej luči je zanimivo razmišljanje Koželja (2004), ki meni, da novo stanovanjsko tkivo danes $\mathrm{v}$ vse manjši meri konstituira $\mathrm{kraj} / \mathrm{mesto}$ ali ga celo razgrajuje. Zato menimo, da bo treba v prihodnje stremeti k takšnemu urbanističnemu razvoju, ki bo stremel k ravnovesju med razvojem in ohranjanjem značilnih morfoloških območij, ki so pomemben element identitete Ljubljane.

\section{Sklep}

$S$ kartiranjem v geografskih informacijskih sistemih, podprtim s terenskim delom ter različnimi podatkovnimi in zgodovinskimi viri smo v raziskavi opredelili 16 stanovanjskih morfoloških območij 
v Ljubljani ter jih natančno prostorsko zamejili in opisali. Pri izdelavi morfološke tipologije smo sledili postavljenim metodološkim izhodiščem, ki temeljijo na treh prvinah: času, obliki in ravni natančnosti. Pričujoča morfološka tipologija je v primerjavi s predhodnimi prostorsko bolj natančna, ima nižjo stopnjo generalizacije in opredeljuje nekatere nove morfološke tipe.

$\mathrm{Z}$ analizo smo ugotovili, da po številu prebivalcev prevladujejo blokovske stanovanjske soseske in novejša območja prostostoječih enostanovanjskih hiš, vendar pa se v pomembnem obsegu pojavljajo tudi drugi morfološki tipi, kot so (pol)urbanizirane vasi in nekdanja predmestja večstanovanjskih hiš, ki zaznamujejo današnjo podobo Ljubljane. Morfološke enote so sicer v povprečju dokaj majhne in prostorsko razdrobljene; številne niso homogene, temveč so preplet različnih morfoloških tipov, v katerih lahko prepoznamo različna zgodovinska obdobja.

Predstavljena morfološka tipologija ima, podobno kot predhodne tipologije, nekatere omejitve in pomanjkljivosti, povezane z uporabljeno metodologijo. Med največjimi izzivi izpostavljamo poimenovanje morfoloških tipov, primerno ravni natančnosti, določitev števila morfoloških tipov in uvrščanje enot v morfološke tipe. Zavedamo se, da naša tipologija ni edina pravilna in ni nujno, da bo širše sprejeta $\mathrm{v}$ drugih strokah. Kljub temu menimo, da predstavlja napredek v primerjavi z dozdajšnjimi tipologija$\mathrm{mi}$, uporabljena metodologija pa je potencialno uporabna tudi za druga slovenska mesta. Ocenjujemo, da so rezultati tipizacije uporabni pri urbanističnem načrtovanju, saj vsebujejo natančne podatke o grajeni strukturi. Obenem so koristna podlaga za nadaljnje analize v urbanizmu in urbani geografiji (na primer prostorska segregacija, kakovost bivalnega okolja), saj gre za prostorske enote, ki so poleg morfologije praviloma homogene tudi po socioekonomski sestavi prebivalstva in lastnostih stanovanj. Dobljeni rezultati so neposredno uporabni tudi za ovrednotenje preteklega in današnjega prostorskega razvoja, tudi kot strokovna podlaga za spreminjanje občinskega prostorskega načrta.

\section{Viri in literatura}

Barvni digitalni ortofoto posnetek DOF 050. Geodetska uprava Republike Slovenije. Ljubljana, 2014. Batista, E. 2010: Zelena jama. DEDI - digitalna enciklopedija naravne in kulturne dediščine na Slovenskem. Medmrežje: http://www.dedi.si/dediscina/235-zelena-jama (25. 5.2016).

Bole, D. 2015: Spreminjanje prometne rabe zemljišč. Georitem 25. Ljubljana.

Carter, H. 1995: The Study of Urban Geography. New York.

Centralni register prebivalstva, Stanje na dan 31.12.2014. Ministrstvo za notranje zadeve. Ljubljana, 2015. Černigoj, N. 2015: Zupančičeva jama. AB: Arhitektov bilten 45, 203-204.

Čerpes, I., Blejec, G., Koželj, J. 2008: Urbanistično načrtovanje: raba prostora, tipologija stanovanjske gradnje, promet, parcelacija. Ljubljana.

Dimitrovska Andrews, K., Mihelič, B., Stanič, I. 2001: Razpoznavna struktura mesta: primer Ljubljane. Urbani izziv 12-2.

Drozg, V. 1995: Morfologija vaških naselij v Sloveniji. Geographica Slovenica 27. Ljubljana.

Drozg, V. 1997: Nekatere značilnosti ustroja Maribora. Geografski vestnik 69.

Drozg, V. 1998a: Kmečka hiša. Geografski atlas Slovenije. Ljubljana.

Drozg, V. 1998b: Tlorisi slovenskih mest. Geografski vestnik 70.

Drozg, V. 2007: Tri paradigme novodobnega razvoja slovenskih mest. Dela 27. DOI: http://dx.doi.org/ 10.4312/dela.27.7.135-147

Drozg, V. 2008: Načini zazidanosti v Mariboru. Podatkovni sloj. Maribor.

Drozg, V. 2013: Tipi novodobne enostanovanjske hiše. Revija za geografijo 8-1.

Evidenca hišnih številk, Stanje na dan 31.12.2014. Geodetska uprava Republike Slovenije. Ljubljana, 2015. Fikfak, A. 2012: Urejanje prostora naselja - sodobna stanovanjska hiša. Urbanistično-planerska delavnica Muta 2011/2012. Muta.

Gauthiez, B. 2004: The history of urban morphology. Urban Morphology 8-2. 
Gazvoda, D. 2001: Vloga in pomen zelenega prostora v novejših slovenskih stanovanjskih soseskah. Urbani izziv 12-2. DOI: http://dx.doi.org/10.5379/urbani-izziv-2001-12-02-004

Hofmeister, B. 1994: Stadtgeographie. Braunschweig.

Ilešič, S. 1979: Pomen fiziognomsko-morfološkega kriterija v današnji geografiji mest. Geographica Slovenica 10. Ljubljana.

Ivanšek, F. 1988: Enodružinska hiša: od prosto stoječe hiše k nizki zgoščeni zazidavi. Ljubljana.

Koselj, N. 2010: Moderna slovenska arhitektura - Radikalne, socialne in kontekstualne prakse. AB: Arhitektov bilten 40, 185-187.

Koželj, J. 2004: Tipologija mestne stanovanjske arhitekture in njena sovisnost z morfologijo mestnega prostora. Razširjeni prostori umetnosti: slovenska umetnost 1985-1995. Ljubljana.

Levy, A. 1999: Urban morphology and the problem of the modern urban fabric: some questions for resarch. Urban Morphology 3-2.

Malešič, M. 2015: Nastanek in rast ljubljanskih stanovanjskih sosesk. AB: Arhitektov bilten 45, 203-204.

Mihelič, B. 1983: Urbanistični razvoj Ljubljane. Ljubljana.

Mihelič, B. 2010: Slovenski urbanizem 1900-1980. AB: Arhitektov bilten 40, 185-187.

Mihelič, B., Humar, M., Nikšič, M. (ur.) 2015: Urbanistični terminološki slovar. Ljubljana.

Milič, M. 2006: Kriza slovenskega urbanizma. AB: Arhitektov bilten 37, 173-174.

Modernistične soseske v Ljubljani. Muzej za arhitekturo in oblikovanje. Ljubljana, 2015.

Novak, M. 1991. Zamudniški vzorci industrializacije: Slovenija na obrobju Evrope. Znanstveno in publicistično središče, Maribor.

Občinski prostorski načrt Mestne občine Ljubljana - izvedbeni del (podatkovni sloj). Oddelek za urejanje prostora Mestne občine Ljubljana. Ljubljana, 2014.

Potočnik, A. 1929: Ljubljana. Zvonček 29-5.

Rebernik, D. 1994: Morfološka in socialnogeografska struktura Celja. Geografski vestnik 66.

Rebernik, D. 1997: Model morfološke in socialnogeografske zgradbe urbanega prostora na primeru Celja, Kopra in Ptuja. Dela 12.

Rebernik, D. 2000: Morfološka zgradba. Ljubljana: geografija mesta. Ljubljana.

Rebernik, D. 2007: Trajnostni prostorski razvoj in novejši procesi v prostorskem razvoju Ljubljane. Dela 27. DOI: http://dx.doi.org/10.4312/dela.27.2.17-38

Rebernik, D. 2008: Urbana geografija. Geografske značilnosti mest in urbanizacije v svetu. Ljubljana. Register nepremičnin, Stanje na dan 15. 12. 2014. Geodetska uprava Republike Slovenije. Ljubljana, 2015.

Režek Kambič, M. 2015: Meščanska stanovanjska arhitektura v Ljubljani 1870-1914 (pozni historizem in secesija). AB: Arhitektov bilten 45, 203-204.

Rozin Šarec, L., Mušič, V., Repič Vogelnik, K., Blejec, M., Lebeničnik, M., Vovk, M. 1976: Posledice in učinki visoke in nizke stanovanjske gradnje na stanovanjsko okolje. Raziskovalno poročilo, Urbanistični inštitut Republike Slovenije. Ljubljana.

Šarac, D. 2013: The influence of wars on settlement formation and development: The case of Ljubljana, Slovenia. Urbani izziv 24-2. DOI: http://dx.doi.org/10.5379/urbani-izziv-en-2013-24-02-001

Turk Niskač, B., Klaus, S., Starec, S. 2010: Urbano življenje ob kmetijah ali ruralno življenje ob stolpnicah? Dilema jasne ločnice med urbanim in ruralnim. Urbani izziv 21-1. DOI: http://dx.doi.org/10.5379/ urbani-izziv-2010-21-01-003

Vernez Moudon, A. 1997: Urban morphology as an emerging interdisciplinary field. Urban morphology 1.

Vogelnik, A. 1938: Stanovanjske razmere v delavskih kolonijah na področju mesta Ljubljane. Kronika slovenskih mest 5-1. Ljubljana.

Vresk, M. 2002: Grad in urbanizacija: Osnove urbane geografije. Zagreb.

Vrišer, I. 1984: Urbana geografija. Ljubljana.

Zakon o prostorskem načrtovanju. Uradni list Republike Slovenije 33/2007. Ljubljana.

Zukin, S. 2010: Naked City: The Death and Life of Authentic Urban Places. New York.

Zupančič, B. 2005: Usode ljubljanskih stavb in ljudi. Ljubljana. 


\section{Summary: Morphological typology of residential areas in Ljubljana}

(translated by Živa Malovrh)

The city is a complicated and complex social and spatial phenomenon. This is most visibly reflected in its urban morphology or how the cityscape is shaped. Urban morphology is the spatial dispersion and the interrelation between the morphological elements in the city space that together form a cityscape that reflects city life of today and of the past (Vrišer 1984; Vresk 2002). The elements of the urban morphology are quite diverse and different authors group them together differently (Vrišer 1984; Hofmeister 1994; Carter 1995; Rebernik 2000; 2008; Čerpes, Blejec in Koželj 2008). Consequently, individual categorizations in morphological areas vary significantly and must also be regionally conditioned (Rebernik 2008).

Ljubljana's long history, significance, and size cause it to have a very diverse morphological structure that has been so far more thoroughly analysed by two studies. Rebernik (2000) used the basis of three morphological elements (town plan, type of building-up, and type of buildings) to determine 10 residential morphological areas. Dimitrovska Andrews, Mihelič, and Stanič (2001) used building age, function, and building-up system to determine 15 homogeneous city areas that provide an identity for the city, as well as develop its historic character. Both studies have a higher level of generalization and both do not define certain morphological areas. The purpose of the article is therefore to create a new, more precise morphological typology of the residential areas in Ljubljana, which can be a useful foundation for urban planning and spatial analysis. To this end, two goals were set:

- To define a methodological ground for mapping the urban morphology that can also be used on other Slovenian cities and

- To pinpoint, analyse, and describe the morphological city areas.

The typification was based on three fundamental principles of urban morphological research: time, form, and resolution. The basic data source for time was the building age as well as other sources that describe the historical and urbanist development of the city and its morphological areas. The form was analysed based on the number of units per building, type of building (height, shape, and size of building, number of floors, shape of facade), the buildings' position relative to the traffic vein, and the buildings' position relative to neighbouring buildings; for this, we relied on the digital ortophoto image (2014), Real estate register (Register ... 2014), and our own field work. The resolution was analysed by attempting to typify smaller units of the city structure and adopting the basic unit of space management from the Municipal spatial plan of the City Municipality of Ljubljana (Občinski ... 2014).

By mapping in the geographical information systems, we defined 16 residential morphological areas with accurate delimitation and descriptions. According to the type of building, we grouped them into 4 groups:

- neighbourhoods of single-family houses (older neighbourhoods of single-unit detached houses, newer neighbourhoods of single-unit detached houses, older terraced houses, newer terraced houses, quarters of urban villas, urbanized villages, and semi-urbanized villages),

- areas of apartment buildings (historical city centre, newer city centre, older suburbs of apartment buildings, older working class neighbourhoods, between-war block apartment buildings),

- mixed single- and multi-unit buildings,

- and high-rise housing estates (post-WWII older apartment buildings, neighbourhoods with newer apartment buildings and contemporary apartment buildings).

We found Ljubljana to be a city with numerous (semi)urbanized villages and older suburbs of apartment buildings, while on average, the morphological units are quite small and fragmented. Some of them are heterogeneous, an intertwining of numerous morphological types with many recognizable historic styles. The majority, 71,451 or approximately one quarter of inhabitants live in neighbourhoods with newer block apartment buildings, while 131,945 inhabitants live in high-rise housing estates, adding up to about one half. Approximately one fifth $(53,624)$ live in newer neighbourhoods of single-fami- 
ly detached houses, while the rest of the morphological types are not as heavily represented, but still have a great impact on the contemporary image of Ljubljana.

We faced numerous problems and challenges during the process of typification: it was not possible to classify and name certain areas unambiguously and we had to use different approaches to process the resolution. It was also a challenge to define the number of types, having to take care that the number of types will still allow the typology to be clear, straightforward, and not overly simplified. However, the new morphological typology of residential areas in Ljubljana is spatially more accurate and complex in comparison to previous ones. The methodology for mapping urban morphology is also potentially useful for other Slovenian cities, while the typification results can be a useful basis for urban planning, future analysis in urbanism and urban geography and the evaluation of previous and contemporary spatial development in Ljubljana. 